\title{
The Effect of Maternal Depression on Infant Attachment: A Systematic Review
}

\author{
Andrzej Śliwerski *®D, Karolina Kossakowska, Karolina Jarecka® ${ }^{\circledR}$, Julita Świtalska and \\ Eleonora Bielawska-Batorowicz \\ Institute of Psychology, University of Lodz, 91-433 Lodz, Poland; karolina.kossakowska@uni.lodz.pl (K.K.); \\ karolina.jarecka@uni.lodz.pl (K.J.); julita.switalska@uni.lodz.pl (J.Ś.); eleonora.batorowicz@uni.lodz.pl (E.B.-B.) \\ * Correspondence: andrzej.sliwerski@uni.lodz.pl
}

Received: 15 March 2020; Accepted: 8 April 2020; Published: 14 April 2020

check for updates

\begin{abstract}
Aims and objectives: The aim of this systematic review was to summarize the key findings of empirical studies assessing the influence of maternal depression on child attachment security measured before 24 months after birth. Method: The study followed the Preferred Reporting Items for Systematic Reviews and Meta-Analyses (PRISMA) statement guidelines. A literature search was conducted on the EBSCO (Academic Search Complete; Health Source: Nursing/Academic Edition; MEDLINE; PsycARTICLES) and PubMed databases, with infant attachment AND depression as search terms with Boolean operators. Study design or sample size did not affect inclusion. After screening, 29 of the 1510 unique publications originally identified were included in the review. Results: The studies reveal an equivocal association between maternal depression and child attachment security. Our findings indicate that depression had a significant influence on the attachment style almost only when diagnosed by structured interview: Depression measured by self-descriptive questionnaires was unrelated to attachment style. Furthermore, postpartum depression was found to be significant only when measured up to six months after childbirth. Conclusion: The relationship between maternal depression and infant attachment is both complex and dynamic, and the possible negative effects of depression might be compensated by maternal involvement in childcare. Therefore, further studies in this area should employ a reliable methodology for diagnosing depression and a suitable time point for measuring it; they should also adopt a multifactorial and prospective approach. It is important to note that breastfeeding/formula feeding was omitted as a factor in the majority of studies.
\end{abstract}

Keywords: maternal depression; prenatal depression; postnatal depression; major depression; infant attachment; systematic review

\section{Introduction}

Depression is one of the main causes of disability worldwide, and its lifetime prevalence ranges from $20 \%$ to $25 \%$ in women [1,2]. Women are more vulnerable to depression than men, and the reproductive years are a particularly critical period for its onset [3]. Depression that occurs during pregnancy is referred to as antenatal or prenatal depression, and depression occurring after childbirth is described as postpartum depression (PPD). The prevalence of prenatal depression increases from $5.4 \%$ in early pregnancy to $10.0 \%$ in late pregnancy [4] and prenatal depression is one of the greatest risk factors for developing PPD [5].

PPD is a common and serious mental health problem, and one that is a source of suffering for both the mother and her offspring. It is often defined as an episode of a major or sometimes minor depressive disorder that occurs anytime within the first year postpartum [6]; however, most episodes begin within two to three months after giving birth $[5,7]$. The prevalence of PPD has been estimated to range from $9 \%$ to $19 \%$ depending on the recognition criteria, the period of time under consideration and population 
type [8]. The prevalence of PPD is 9.6\% among women living in high-income countries $[9,10]$ and $19.6 \%$ in low-income and middle-income countries [11]. For comparison, the prevalence of MD among non-pregnant women of childbearing age is $4.8 \%$ [12]

The majority of studies examining depression suggest that it may be associated with problems in the formation of the bond between mother and child [13-16], particularly in women with a dual/disorganized attachment style [17]. Depressive mothers develop a less-intense relationship with their children, experience more stress, perceive their children in a more negative way and may assess them as less securely attached than non-depressive mothers [14]. Some experience lowered maternal instinct, as well as greater hostility and aggressive impulses, and a feeling of rejection toward their own children [18].

Maternal depression also influences the affective state of the infant and impairs their capacity for repairing states of miscoordination. As a result, the infants develop negative affective states that disrupt their social relations. This impact is associated primarily with severe maternal depression but can also manifest in mothers who have only high levels of depressive symptoms [19]. However, findings from longitudinal studies indicate that the severity and chronicity of maternal depression are associated with higher levels of later childhood behavioural problems [20,21]. Moreover, male infants are more vulnerable than female infants to maternal depression [19,22]. At nine months, the infants of depressed mothers manifest lower social engagement, fewer mature regulatory behaviours and more negative emotionality, and higher cortisol reactivity $[23,24]$. Some studies have found that the detrimental effect of maternal depression is intensified in mothers with comorbid diagnosis such as anxiety or a personality disorder [25-27], and others show that the influence of maternal depression on child development depends on maternal sensitivity and quality of parenting [23,28]. As sensitive parenting requires an accurate and empathic response to signals from the child, the process can be disrupted by changes in the mental state of the parent.

Some studies have indicated that maternal depression has adverse effects on mother-child bonding and child development, and these examine a variety of factors; however, there is an urgent need to determine the influence of maternal depression on the development of the attachment security of the child and to identify the factors that play crucial roles in this process. Studies in this area tend to focus on individual sets of variables and lack the global analysis needed to gain a comprehensive understanding of the effects of maternal depression. No such systematic review has yet been carried out in this area; existing studies focus either on a broader developmental context [29] or on the effects of depression treatment [30].

The aim of this review is to identify and summarize the key findings of empirical studies assessing the influence of maternal depression on the relationship between mother and child, and on child attachment security, measured up to 24 months after birth. It was decided to use 24 months as a cut-off age for three reasons: (1) to concentrate the analysis on the period of life when children depend mostly on their parents, and thus might be highly affected by any type of parental disturbances or abnormalities; (2) to indicate that intense reorganization takes place in the brain, and the changes are directly related to the attachment style [31]; and (3) to look at the effects of maternal depression in fairly similar age groups and thus control for a child's developmental stage. Thus, the review places particular attention on the period when depression occurs and its most visible effects for attachment security. It also attempts to identify both the protective and adverse factors that might modify the influence of maternal depression.

\section{Materials and Methods}

A systematic review was performed of scientific papers examining the influence of maternal depression on child attachment security. Within this review, the term depression was applied to either major depression, prenatal depression occurring during pregnancy, or postpartum depression occurring during the first year after delivery. 


\subsection{Inclusion and Exclusion Criteria}

To qualify for review, the studies were required to meet the following three inclusion criteria: (a) the study was empirical and published in an English-language peer reviewed journal from 1 January 1981 to 31 December 2018; (b) child attachment was assessed up to 24 months after birth; (c) the study assessed both maternal depression and child attachment style. Studies were included regardless of the study design or sample size.

Articles were excluded if they were (a) non-empirical (such as reviews, commentaries, or letters to editors); (b) the child was older than 24 months when measuring attachment style; (c) the study assessed only mother-child bond; (d) the study assessed the efficacy of therapeutic intervention; (e) depression was not considered as a separate variable i.e., depression was aggregated into cumulative risk score, see: [32].

\subsection{Research Strategy and Data Extraction}

The present review followed the guidelines given in the Preferred Reporting Items for Systematic Reviews and Meta-Analyses (PRISMA) Statement [33], using a three-step procedure to identify relevant studies. A systematic search of literature was conducted on the following electronic databases: EBSCO (Academic Search Complete; Health Source: Nursing/Academic Edition; MEDLINE; PsycARTICLES) and PubMed. The search strategy comprised the terms infant attachment and depression combined with the Boolean operator AND. The search area included the title, abstract, key words, topic and main text of the article (if available). Results were limited to studies on humans.

The first screening of EBSCO and PubMed identified 1718 articles (1102 and 616 hits respectively). After removing duplicates, 1510 unique publications were identified. The abstracts were screened by four reviewers (A.S., K.K., K.J., J.S.) to obtain potentially relevant publications. Abstracts that did not address the association between maternal depression and child attachment style were excluded. When it was unclear from the titles or abstracts whether all inclusion criteria were met, the papers were subjected to closer inspection: the full texts of these articles were examined before the decision was made to include them or not. Of these works, 68 papers were identified as potentially relevant articles. In this stage of the screening, the articles with abstracts that appeared relevant were selected for full-text evaluation.

Thirty-nine papers did not meet all inclusion criteria and so were excluded. Twenty-nine papers were, therefore, included in the present review. The following data were extracted to Microsoft Excel spreadsheets with the following specified headings: country where the study was performed, study design, main objectives, information about participants, measurement of attachment style and maternal depression and main results of the research. Another reviewer (EB) screened all data independently to confirm whether the articles met the inclusion criteria. Uncertainty was resolved by consensus among all five reviewers. The study selection process is shown in the flow diagram (Figure 1) based on the criteria of Vu-Ngoc et al. [34]. One of the included studies employed intervention [35]; however, it was included in the present analysis as the measurement of depression and attachment was performed before the intervention. 


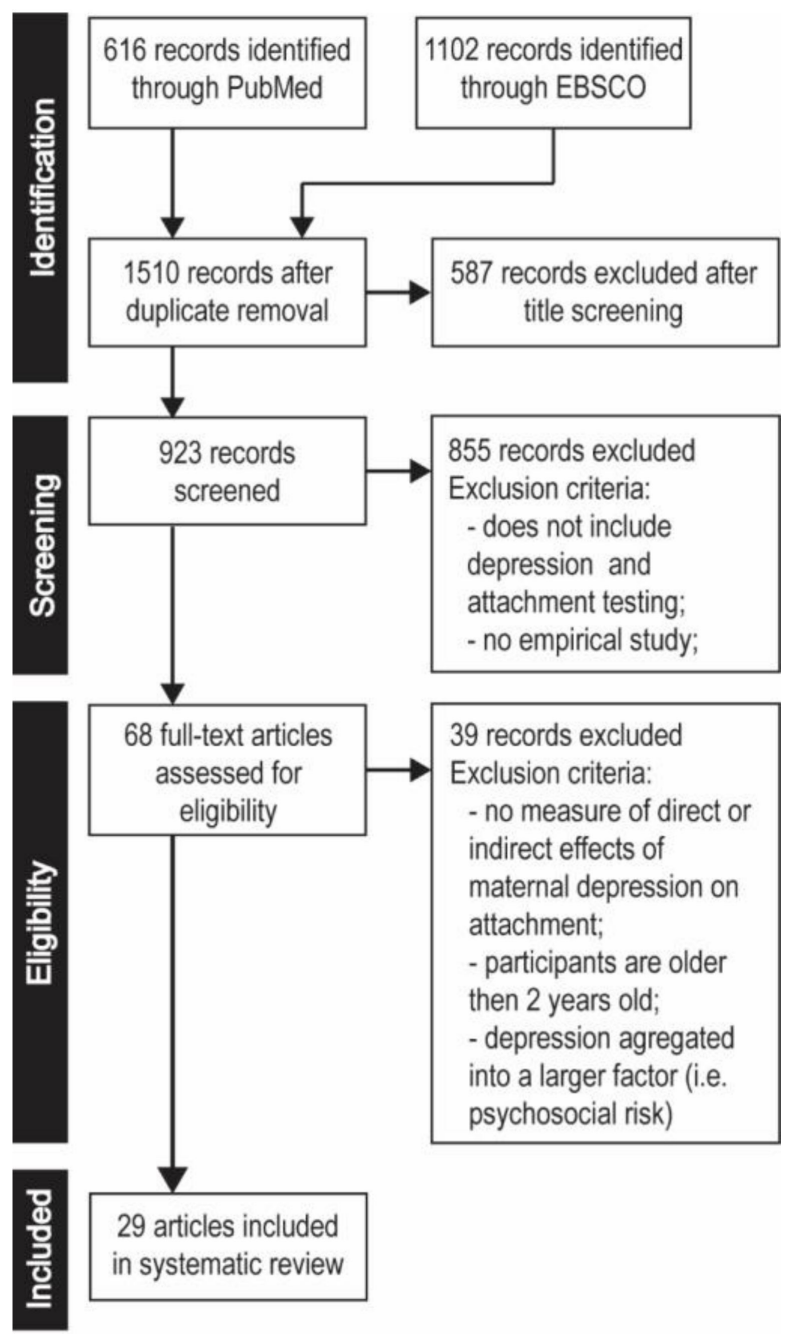

Figure 1. Flowchart of the search and systematic review process.

\subsection{Risk of Bias Assessment}

During the study extraction process, information was collected to determine the risk of bias within each included study and the risk of bias across studies, as well as whether the data obtained from the included studies was valid. The quality assessment influenced the analysis, interpretation and conclusions of this report.

Multiple publications deriving from the same study were identified using the criteria given by Higgins and Green [36]. Such duplicate publications were detected by the following steps: checking author names, study location and setting, numbers of participants, baseline data and duration of the study. None of the studies included in this review were found to be based on the same sample.

To assess the risk of bias in individual studies, the final quality assessment included several factors. Firstly, classification to the group was examined: random allocation to groups was not permitted due to the specificity of the research on depression. However, the baseline characteristics of the comparison groups were reviewed, as were the exclusion criteria and attrition rate, existence of blind attachment assessment and the experience of the coders in scoring the attachment style.

\subsection{Quality Assessment}

Each paper included in the systematic review was assessed according to the quality of the study design, using the criteria outlined in Higgins, Altman and Stern [37]. The review included papers of all study designs, as restricting the range to randomised control trials (RCT) would be unrealistic 
and not reflect the true knowledge about the influence of maternal depression on child attachment style. The quality assessment was conducted by two reviewers independently (A.S., K.K.). The inter-rater agreement was calculated (Kappa $=0.743)$ and all disagreements in assessment were resolved by the third author (EB) (see Table S1). As blind assessment has been found to have little influence on this procedure [38], the authors of the papers were not hidden during the quality evaluation process. The following criteria were used to assess the quality of the presented studies:

(a) Sample size: an adequate minimum sample size was regarded as 30 participants in each compared group;

(b) Representative of study population: representative and adequate study sample (should vary in demographic characteristics);

(c) Low attrition: below $30 \%$ of the initial sample;

(d) Validated measuring methods: standardized with given validity and reliability; proper adaptation if the measurement method was conducted in a different country than its origin;

(e) Coding experience: the authors possessed training and experience in assessing attachment;

(f) Statistical analysis: appropriately described and correct;

(g) Assessment procedure: double-blind procedure in the attachment assessment;

(h) Conclusions which were consistent with results;

(i) Aim of the study: direct/indirect assessment of the influence of depression on attachment style.

The quality of the research was evaluated using a points system $(+1=$ yes, $0=$ unclear, $-1=$ no) for all specified criteria. The maximum amount of points that a study could achieve was 9 and the minimum was 0 : a possible evaluation below zero would be awarded a value of 0 . The quality score of every study is given in last column of Tables 1 and 2.

\section{Results}

The information about the papers, their design and research questions, sample size, methodology, main findings, and quality score were placed in two tables. Table 1 includes studies in which a clinical interview was used to diagnose depression and Table 2 for self-report questionnaires. The majority of the articles were published at some point during the last 10 years, i.e., 2007 to $2018(n=15 ; 52 \%)$, nine articles were published between 2000 and 2007 (31\%) and only a few were published before 2000 $(n=5 ; 17 \%)$. Except for five studies which had a cross-sectional design [39-43] most studies were longitudinal. A detailed description of demographic data can be found in Supplementary Materials. 
Table 1. Details of the studies measuring the impact of maternal depression on attachment security which used the clinical interview to diagnose depression.

\begin{tabular}{|c|c|c|c|c|c|}
\hline $\begin{array}{l}\text { Study (Year), Country } \\
\text { Study Design. }\end{array}$ & $\begin{array}{c}\text { Main Objectives/ } \\
\text { Research Questions }\end{array}$ & $\begin{array}{l}\text { Participant Details/ } \\
\text { Sample Size } \\
\text { N; M Mother's Age } \\
\text { (Standard Deviation, } \\
\text { SD) }\end{array}$ & $\begin{array}{l}\text { Attachment and } \\
\text { Depression } \\
\text { Measurement: Name of } \\
\text { a Tool and the Time } \\
\text { When Administered (in } \\
\text { Trimester if Prenatally or } \\
\text { Months if Postnatally) }\end{array}$ & Results & Study Quality Score \\
\hline $\begin{array}{l}\text { [47] (2016), Denmark } \\
\text { longitudinal study }\end{array}$ & $\begin{array}{l}\text { To examine the role of } \\
\text { personality disorders in } \\
\text { the association between } \\
\text { maternal postpartum } \\
\text { depression and } \\
\text { infant-mother attachment } \\
\text { in a low-risk sample. }\end{array}$ & $\begin{array}{l}\text { Mothers with personality } \\
\text { disorders }(\mathrm{PD}) \text { and } \\
\text { mothers from low-risk } \\
\text { sample. } \\
\quad N=80 ; \\
(\mathrm{M} \text { age }=30.5, \mathrm{SD}=4.12)\end{array}$ & $\begin{array}{l}\text { SSP: } 13 \text { months; } \\
\text { PSE: } 2 \text { months; } \\
\text { EPDS: } 2 \text { months }\end{array}$ & $\begin{array}{l}\text { Postpartum depression } \\
\text { was associated with } \\
\text { attachment insecurity } \\
\text { only if the mother also } \\
\text { had a personality disorder } \\
\text { diagnosis. Infants of } \\
\text { depressed mothers } \\
\text { without co-morbid } \\
\text { personality disorders did } \\
\text { not differ from infants of } \\
\text { mothers with no } \\
\text { psychopathology. These } \\
\text { results suggest that } \\
\text { co-existing personality } \\
\text { disorders may be crucial } \\
\text { in understanding how } \\
\text { postpartum depression } \\
\text { impacts on parenting and } \\
\text { infant social-emotional } \\
\text { development.. }\end{array}$ & $\begin{array}{l} \\
\text { Low attrition rate, } \\
\text { validated methods, clear } \\
\text { statistical analysis and } \\
\text { direct measurement of } \\
\text { depression-attachment } \\
\text { influence, double-blind } \\
\text { procedure used by } \\
\text { experienced coders. } \\
\text { Inadequate sample size } \\
\text { and no representative } \\
\text { group of mothers from } \\
\text { low-risk sample. }\end{array}$ \\
\hline
\end{tabular}


Table 1. Cont.

\begin{tabular}{|c|c|c|c|c|c|}
\hline $\begin{array}{l}\text { Study (Year), Country } \\
\text { Study Design. }\end{array}$ & $\begin{array}{c}\text { Main Objectives/ } \\
\text { Research Questions }\end{array}$ & $\begin{array}{l}\text { Participant Details/ } \\
\text { Sample Size } \\
\text { N; M Mother's Age } \\
\text { (Standard Deviation, } \\
\text { SD) }\end{array}$ & $\begin{array}{l}\text { Attachment and } \\
\text { Depression } \\
\text { Measurement: Name of } \\
\text { a Tool and the Time } \\
\text { When Administered (in } \\
\text { Trimester if Prenatally or } \\
\text { Months if Postnatally) }\end{array}$ & Results & Study Quality Score \\
\hline $\begin{array}{l}\text { [44] (2013), USA } \\
\text { longitudinal study }\end{array}$ & $\begin{array}{l}\text { To examine associations } \\
\text { between maternal } \\
\text { antenatal depression and } \\
\text { infant disorganization at } \\
12 \text { months. A secondary } \\
\text { aim was to test the roles of } \\
\text { maternal postpartum } \\
\text { depression and maternal } \\
\text { parenting quality as } \\
\text { potential moderators of } \\
\text { this association. }\end{array}$ & $\begin{array}{l}\text { Only mothers with at least } \\
\text { one major depressive } \\
\text { episode before pregnancy. } \\
\qquad \mathrm{N}=79 ; \\
(\mathrm{M} \text { age }=30.3 ; \mathrm{SD}=5.4)\end{array}$ & $\begin{array}{c}\text { SSP: } 12 \text { months; } \\
\text { BDI-II: } 1 \text { st and 2nd } \\
\text { trimester; } 6 \text { and } 12 \\
\text { months; } \\
\text { SCID-I/P: } 1 \text { st trimester }\end{array}$ & $\begin{array}{c}\text { Attachment } \\
\text { disorganization was } \\
\text { strongly correlated with } \\
\text { antenatal depression. } \\
\text { Maternal parenting } \\
\text { quality moderated this } \\
\text { association, as exposure to } \\
\text { higher levels of maternal } \\
\text { depressive symptoms } \\
\text { during pregnancy was } \\
\text { only associated with } \\
\text { higher rates of infant } \\
\text { disorganized attachment } \\
\text { when maternal parenting } \\
\text { at three months was less } \\
\text { optimal. No significant } \\
\text { effects were found for } \\
\text { postpartum depression. }\end{array}$ & $\begin{array}{c} \\
\text { Adequate sample size, } \\
\text { validated methods, clear } \\
\text { methodology and } \\
\text { statistical analysis, direct } \\
\text { measurement of } \\
\text { depression-attachment } \\
\text { influence. No information } \\
\text { about attrition rate, } \\
\text { double-blind procedure or } \\
\text { coder experience, no } \\
\text { representative high-risk } \\
\text { study population. }\end{array}$ \\
\hline
\end{tabular}


Table 1. Cont.

\begin{tabular}{|c|c|c|c|c|c|}
\hline $\begin{array}{l}\text { Study (Year), Country } \\
\text { Study Design. }\end{array}$ & $\begin{array}{c}\text { Main Objectives/ } \\
\text { Research Questions }\end{array}$ & $\begin{array}{l}\text { Participant Details/ } \\
\text { Sample Size } \\
\text { N; M Mother's Age } \\
\text { (Standard Deviation, } \\
\text { SD) }\end{array}$ & $\begin{array}{l}\text { Attachment and } \\
\text { Depression } \\
\text { Measurement: Name of } \\
\text { a Tool and the Time } \\
\text { When Administered (in } \\
\text { Trimester if Prenatally or } \\
\text { Months if Postnatally) }\end{array}$ & Results & Study Quality Score \\
\hline $\begin{array}{l}\text { [46] (2012), Netherlands } \\
\text { longitudinal study }\end{array}$ & $\begin{array}{l}\text { To examine the effects of } \\
\text { maternal history of } \\
\text { depressive disorder and } \\
\text { the effects of depressive } \\
\text { symptoms during } \\
\text { pregnancy and early } \\
\text { postpartum period on } \\
\text { attachment insecurity. }\end{array}$ & $\begin{array}{c}\text { A varied and } \\
\text { representative sample } \\
\text { with socio-economic } \\
\text { diversity. } \\
\quad N=627 ; \\
(\mathrm{M} \text { age }=32 ; \mathrm{SD}=\mathrm{NA})\end{array}$ & $\begin{array}{c}\text { SSP: } 14 \text { months; } \\
\text { BSI: 2nd trimester and } 2 \\
\text { months; } \\
\text { EPDS: 2months; } \\
\text { CIDI: 3rd trimester }\end{array}$ & $\begin{array}{l}\text { Insecure and disorganized } \\
\text { attachment patterns were } \\
\text { not related to maternal } \\
\text { lifetime diagnosis of } \\
\text { depression regardless of } \\
\text { its severity. Higher } \\
\text { maternal BSI depression } \\
\text { score during pregnancy } \\
\text { and BSI/EPDS score } \\
\text { during postpartum period } \\
\text { were not related to } \\
\text { infant-mother attachment } \\
\text { insecurity or } \\
\text { disorganization at } 14 \\
\text { months. }\end{array}$ & $\begin{array}{c} \\
\text { Adequate and } \\
\text { representative sample } \\
\text { size, low attrition rate, } \\
\text { validated methods, clear } \\
\text { statistical analysis and } \\
\text { direct measurement of } \\
\text { depression-attachment } \\
\text { influence, double-blind } \\
\text { procedure used by } \\
\text { experienced coders. }\end{array}$ \\
\hline
\end{tabular}


Table 1. Cont.

\begin{tabular}{|c|c|c|c|c|c|}
\hline $\begin{array}{l}\text { Study (Year), Country } \\
\text { Study Design. }\end{array}$ & $\begin{array}{c}\text { Main Objectives/ } \\
\text { Research Questions }\end{array}$ & $\begin{array}{l}\text { Participant Details/ } \\
\text { Sample Size } \\
\text { N; M Mother's Age } \\
\text { (Standard Deviation, } \\
\text { SD) }\end{array}$ & $\begin{array}{l}\text { Attachment and } \\
\text { Depression } \\
\text { Measurement: Name of } \\
\text { a Tool and the Time } \\
\text { When Administered (in } \\
\text { Trimester if Prenatally or } \\
\text { Months if Postnatally) }\end{array}$ & Results & Study Quality Score \\
\hline $\begin{array}{c}\text { [40] (2011), USA } \\
\text { prospective cross sectional }\end{array}$ & $\begin{array}{l}\text { To examine associations } \\
\text { between maternal } \\
\text { depression and maternal } \\
\text { expressed emotion } \\
\text { (self-criticism, } \\
\text { child-criticism), child } \\
\text { internalizing and } \\
\text { externalizing behaviors, } \\
\text { and attachment insecurity. }\end{array}$ & $\begin{array}{l}\text { Mothers with major } \\
\text { depression with at least } \\
\text { high-school education } \\
\text { and good or very good } \\
\text { socio-economic status. } \\
\quad N=198 ; \\
(\mathrm{M} \text { age }=31.7 ; \mathrm{SD}=4.68)\end{array}$ & $\begin{array}{l}\text { SSP: } 20 \text { months; } \\
\text { BDI: } 20 \text { months; } \\
\text { DIS-III-R: } 20 \text { months }\end{array}$ & $\begin{array}{l}\text { The depressed and } \\
\text { nondepressed groups } \\
\text { differed significantly } \\
\text { regarding the main study } \\
\text { variables, with depressed } \\
\text { mothers evidencing } \\
\text { higher child-criticism and } \\
\text { self-criticism and having } \\
\text { toddlers with higher } \\
\text { levels of internalizing } \\
\text { symptoms, externalizing } \\
\text { symptoms, and } \\
\text { attachment insecurity. } \\
\text { Results revealed that } \\
\text { children of mothers with } \\
\text { higher self-criticism had a } \\
\text { significantly higher } \\
\text { probability of being } \\
\text { classified as insecurely } \\
\text { attached. However, } \\
\text { child-criticism was not a } \\
\text { significant mediator of the } \\
\text { association between } \\
\text { maternal depression and } \\
\text { child attachment } \\
\text { insecurity. }\end{array}$ & $\begin{array}{c} \\
\text { Adequate sample size, } \\
\text { validated methods, clear } \\
\text { statistical analysis and } \\
\text { direct measurement of } \\
\text { depression-attachment } \\
\text { influence, double-blind } \\
\text { procedure used by } \\
\text { experienced coders. No } \\
\text { information about } \\
\text { attrition rate, no } \\
\text { representative low-risk } \\
\text { study population. }\end{array}$ \\
\hline
\end{tabular}


Table 1. Cont.

\begin{tabular}{|c|c|c|c|c|c|}
\hline $\begin{array}{l}\text { Study (Year), Country } \\
\text { Study Design. }\end{array}$ & $\begin{array}{c}\text { Main Objectives/ } \\
\text { Research Questions }\end{array}$ & $\begin{array}{l}\text { Participant Details/ } \\
\text { Sample Size } \\
\text { N; M Mother's Age } \\
\text { (Standard Deviation, } \\
\text { SD) }\end{array}$ & $\begin{array}{l}\text { Attachment and } \\
\text { Depression } \\
\text { Measurement: Name of } \\
\text { a Tool and the Time } \\
\text { When Administered (in } \\
\text { Trimester if Prenatally or } \\
\text { Months if Postnatally) }\end{array}$ & Results & Study Quality Score \\
\hline $\begin{array}{l}\text { [48] (2009), USA } \\
\text { longitudinal study }\end{array}$ & $\begin{array}{l}\text { To examine the impact of } \\
\text { maternal depression on } \\
\text { attachment security and } \\
\text { on the representation of } \\
\text { the parents by the child. }\end{array}$ & $\begin{array}{l}\text { Mothers with major } \\
\text { depression with at least } \\
\text { high-school education } \\
\text { and good or very good } \\
\text { socio-economic status. } \\
\quad N=131 ; \\
\text { (M age = NA; SD = NA) }\end{array}$ & $\begin{array}{l}\text { SSP: } 20 \text { and } 36 \text { months; } \\
\text { BDI: } 20,36 \text { and } 48 \text { months; } \\
\text { DIS-III-R: } 20 \text { months }\end{array}$ & $\begin{array}{l}\text { At } 20 \text { and } 36 \text { months, the } \\
\text { distribution of attachment } \\
\text { classifications differed } \\
\text { significantly between the } \\
\text { depressed and } \\
\text { nondepressed groups. } \\
\text { Lower rates of secure and } \\
\text { higher rates of } \\
\text { disorganized attachment } \\
\text { were found for the } \\
\text { depressed group. }\end{array}$ & $\begin{array}{c} \\
\text { Adequate and } \\
\text { representative sample } \\
\text { size, validated methods, } \\
\text { clear statistical analysis } \\
\text { and direct measurement } \\
\text { of depression-attachment } \\
\text { influence, used } \\
\text { double-blind procedure } \\
\text { by experienced coders. } \\
\text { High attrition rate. }\end{array}$ \\
\hline
\end{tabular}


Table 1. Cont.

\begin{tabular}{|c|c|c|c|c|c|}
\hline $\begin{array}{l}\text { Study (Year), Country } \\
\text { Study Design. }\end{array}$ & $\begin{array}{c}\text { Main Objectives/ } \\
\text { Research Questions }\end{array}$ & $\begin{array}{l}\text { Participant Details/ } \\
\text { Sample Size } \\
\text { N; M Mother's Age } \\
\text { (Standard Deviation, } \\
\text { SD) }\end{array}$ & $\begin{array}{l}\text { Attachment and } \\
\text { Depression } \\
\text { Measurement: Name of } \\
\text { a Tool and the Time } \\
\text { When Administered (in } \\
\text { Trimester if Prenatally or } \\
\text { Months if Postnatally) }\end{array}$ & Results & Study Quality Score \\
\hline $\begin{array}{c}\text { [49] (2006), Australia } \\
\text { longitudinal study }\end{array}$ & $\begin{array}{l}\text { To explore whether a } \\
\text { mother's own state of } \\
\text { mind regarding } \\
\text { attachment moderated the } \\
\text { association between } \\
\text { postpartum depression } \\
\text { and insecure } \\
\text { mother-child attachment. }\end{array}$ & $\begin{array}{c}\text { A varied and } \\
\text { representative sample } \\
\text { with socio-economic } \\
\text { diversity. } \\
\quad N=111 ; \\
\text { (M age }=31.4 ; \mathrm{SD}=4.2)\end{array}$ & $\begin{array}{l}\text { SSP: } 15 \text { months; } \\
\text { CIDI: } 4 \text { and } 12 \text { months; } \\
\text { CES-D: } 4,12 \text { and } 15 \\
\text { months }\end{array}$ & $\begin{array}{l}\text { Mothers diagnosed as } \\
\text { depressed were more } \\
\text { likely to have an insecure } \\
\text { state of mind regarding } \\
\text { attachment. Infants of } \\
\text { chronically depressed } \\
\text { mothers were more likely } \\
\text { to be insecurely attached. } \\
\text { However, the relationship } \\
\text { between maternal } \\
\text { depression and child } \\
\text { attachment was } \\
\text { moderated by maternal } \\
\text { attachment state of mind. } \\
\text { When mothers were } \\
\text { depressed and also had an } \\
\text { insecure state of mind, } \\
\text { their children were highly } \\
\text { likely to be insecurely } \\
\text { attached. }\end{array}$ & $\begin{array}{c} \\
\text { Adequate and } \\
\text { representative sample } \\
\text { size, low attrition rate, } \\
\text { validated methods, clear } \\
\text { statistical analysis and } \\
\text { direct measurement of } \\
\text { depression-attachment } \\
\text { influence, double-blind } \\
\text { procedure used by } \\
\text { experienced coders. }\end{array}$ \\
\hline
\end{tabular}


Table 1. Cont.

\begin{tabular}{|c|c|c|c|c|c|}
\hline $\begin{array}{l}\text { Study (Year), Country } \\
\text { Study Design. }\end{array}$ & $\begin{array}{c}\text { Main Objectives/ } \\
\text { Research Questions }\end{array}$ & $\begin{array}{l}\text { Participant Details/ } \\
\text { Sample Size } \\
\text { N; M Mother's Age } \\
\text { (Standard Deviation, } \\
\text { SD) }\end{array}$ & $\begin{array}{l}\text { Attachment and } \\
\text { Depression } \\
\text { Measurement: Name of } \\
\text { a Tool and the Time } \\
\text { When Administered (in } \\
\text { Trimester if Prenatally or } \\
\text { Months if Postnatally) }\end{array}$ & Results & Study Quality Score \\
\hline $\begin{array}{l}\text { [50] (2005), South Africa } \\
\text { longitudinal study }\end{array}$ & $\begin{array}{l}\text { To evaluate how early } \\
\text { disturbances in } \\
\text { mother-infant interactions } \\
\text { might be related to infant } \\
\text { attachment problems. To } \\
\text { examine the effect of } \\
\text { wider contextual } \\
\text { influences on infant } \\
\text { attachment, including the } \\
\text { mother's experience of } \\
\text { depression (both at } 2 \text { and } \\
\text { at } 18 \text { months), the degree } \\
\text { of support she received } \\
\text { from her partner and } \\
\text { others, and } \\
\text { socio-economic status. }\end{array}$ & $\begin{array}{l}\text { Mothers from a high-risk } \\
\text { (low income) group. } \\
\quad N=147 ; \\
\text { (M age = 26.8; SD = NA) }\end{array}$ & $\begin{array}{l}\text { SSP: } 18 \text { months; } \\
\text { SCID: } 2 \text { and } 18 \text { months }\end{array}$ & $\begin{array}{l}\text { Mothers with postpartum } \\
\text { depression at two months } \\
\text { were more likely to have } \\
\text { children who were } \\
\text { insecurely attached. } \\
\text { Mothers who were less } \\
\text { sensitive, more often } \\
\text { intrusive, coercive } \\
\text { (maternal intrusiveness), } \\
\text { and displayed more } \\
\text { maternal remoteness at } \\
\text { two months postpartum } \\
\text { were more likely to have } \\
\text { insecurely attached } \\
\text { children. Mothers who } \\
\text { were less sensitive, highly } \\
\text { intrusive-coercive at } 18 \\
\text { months of a child's life } \\
\text { also were more likely to } \\
\text { have insecurely attached } \\
\text { children. Mothers of } \\
\text { secure children were more } \\
\text { likely to report that they } \\
\text { felt supported by their } \\
\text { partner than insecure ones. } \\
\text { Unwanted pregnancy, } \\
\text { unwanted baby, maternal } \\
\text { depression at } 18 \text { months, } \\
\text { remote-disengaged } \\
\text { behavior at } 18 \text { months } \\
\text { were not related to the } \\
\text { style of infant attachment. }\end{array}$ & $\begin{array}{c} \\
\text { Adequate sample size, } \\
\text { low attrition rate, } \\
\text { validated methods, clear } \\
\text { statistical analysis and } \\
\text { direct measurement of } \\
\text { depression-attachment } \\
\text { influence, double-blind } \\
\text { procedure used by } \\
\text { experienced coders. No } \\
\text { representative group of } \\
\text { mothers from a high-risk } \\
\text { sample. }\end{array}$ \\
\hline
\end{tabular}


Table 1. Cont

\begin{tabular}{|c|c|c|c|c|c|}
\hline $\begin{array}{l}\text { Study (Year), Country } \\
\text { Study Design. }\end{array}$ & $\begin{array}{c}\text { Main Objectives/ } \\
\text { Research Questions }\end{array}$ & $\begin{array}{l}\text { Participant Details/ } \\
\text { Sample Size } \\
\text { N; M Mother's Age } \\
\text { (Standard Deviation, } \\
\text { SD) }\end{array}$ & $\begin{array}{l}\text { Attachment and } \\
\text { Depression } \\
\text { Measurement: Name of } \\
\text { a Tool and the Time } \\
\text { When Administered (in } \\
\text { Trimester if Prenatally or } \\
\text { Months if Postnatally) }\end{array}$ & Results & Study Quality Score \\
\hline $\begin{array}{l}\text { [51] (2003), Switzerland } \\
\text { longitudinal study }\end{array}$ & $\begin{array}{l}\text { To examine the effect of } \\
\text { postpartum depression on } \\
\text { the mother-child } \\
\text { relationship. }\end{array}$ & $\begin{array}{c}\text { Mothers with postpartum } \\
\text { depression and control } \\
\text { group. } \\
N=70 ; \\
(\mathrm{M} \text { age }=29 ; \mathrm{SD}=\mathrm{NA})\end{array}$ & $\begin{array}{c}\text { SSP: } 18 \text { months; } \\
\text { Diagnostic interview: last } \\
\text { trimester; } 3 \text { and } 19 \\
\text { months; } \\
\text { EPDS: } 3 \text { and } 18 \text { months }\end{array}$ & $\begin{array}{l}\text { Infants of non-depressed } \\
\text { mothers were more likely } \\
\text { to be securely attached to } \\
\text { their mother. Mild or } \\
\text { moderate depressive } \\
\text { symptomatology, as } \\
\text { detected at three months } \\
\text { postpartum, had an } \\
\text { impact } 15 \text { months later on } \\
\text { the child's development } \\
\text { and on mother-child } \\
\text { interaction, despite the } \\
\text { fact that most mothers no } \\
\text { longer presented } \\
\text { depressive symptoms at } \\
18 \text { months. Boys were } \\
\text { shown to be more } \\
\text { resistant than girls. }\end{array}$ & $\begin{array}{c} \\
\text { Adequate sample size } \\
\text { with high attrition rate. } \\
\text { Validated methods, clear } \\
\text { methodology and } \\
\text { statistical analysis and } \\
\text { direct measurement of } \\
\text { depression-attachment } \\
\text { influence. No information } \\
\text { about coders experience } \\
\text { or double-blind } \\
\text { procedure. No clear } \\
\text { information if study } \\
\text { population is } \\
\text { representative. }\end{array}$ \\
\hline $\begin{array}{l}\text { [25] (2001), USA } \\
\text { longitudinal study }\end{array}$ & $\begin{array}{l}\text { To examine relations } \\
\text { between maternal } \\
\text { depression (in pure and } \\
\text { comorbid forms) and } \\
\text { mother-infant } \\
\text { interactions, infant } \\
\text { attachment, and toddler } \\
\text { social-emotional problems } \\
\text { and competencies. }\end{array}$ & $\begin{array}{c}\text { A varied and } \\
\text { representative sample } \\
\text { with socio-economic } \\
\text { diversity. } \\
N=69 ; \\
(\mathrm{M} \text { age }=31.9 ; \mathrm{SD}=4.88)\end{array}$ & $\begin{array}{c}\text { SSP: } 14 \text { months; } \\
\text { SCID-NP: } 4 \text { and } 14 \\
\text { months; } \\
\text { CES-D: prenatally and } 4 \\
\text { and } 14 \text { and } 30 \text { months }\end{array}$ & $\begin{array}{l}\text { A history of depression } \\
\text { and other disorders } \\
\text { increased risk for infant } \\
\text { insecure attachment. } \\
\text { Higher incidence of } \\
\text { insecure attachment was } \\
\text { observed in infants of the } \\
\text { comorbid group as } \\
\text { compared with infants of } \\
\text { the pure depression group } \\
\text { and no-psychopathology } \\
\text { group, but no differences } \\
\text { between the pure } \\
\text { depression and } \\
\text { no-psychopathology } \\
\text { groups were found. }\end{array}$ & $\begin{array}{c} \\
\text { Representative but } \\
\text { inadequate sample size } \\
\text { with high attrition rate. } \\
\text { Validated methods, clear } \\
\text { methodology and } \\
\text { statistical analysis, direct } \\
\text { measurement of } \\
\text { depression-attachment } \\
\text { influence, double-blind } \\
\text { procedure used by } \\
\text { experienced coders. }\end{array}$ \\
\hline
\end{tabular}


Table 1. Cont.

\begin{tabular}{|c|c|c|c|c|c|}
\hline $\begin{array}{l}\text { Study (Year), Country } \\
\text { Study Design. }\end{array}$ & $\begin{array}{c}\text { Main Objectives/ } \\
\text { Research Questions }\end{array}$ & $\begin{array}{l}\text { Participant Details/ } \\
\text { Sample Size } \\
\text { N; M Mother's Age } \\
\text { (Standard Deviation, } \\
\text { SD) }\end{array}$ & $\begin{array}{l}\text { Attachment and } \\
\text { Depression } \\
\text { Measurement: Name of } \\
\text { a Tool and the Time } \\
\text { When Administered (in } \\
\text { Trimester if Prenatally or } \\
\text { Months if Postnatally) }\end{array}$ & Results & Study Quality Score \\
\hline $\begin{array}{l}\text { [52](1998), USA } \\
\text { longitudinal study }\end{array}$ & $\begin{array}{l}\text { To examine the direct } \\
\text { influences of maternal } \\
\text { depression on child } \\
\text { development, as well as } \\
\text { the role of contextual risks } \\
\text { that may be particularly } \\
\text { heightened in families } \\
\text { with depressed parents. }\end{array}$ & $\begin{array}{l}\text { Mothers with at least } \\
\text { high-school education } \\
\text { and good or very good } \\
\text { socio-economic status in } \\
\text { relationships with the } \\
\text { child's father. } \\
\quad N=156 ; \\
\text { (M age }=31.8 ; \mathrm{SD}=4.57)\end{array}$ & $\begin{array}{c}\text { AQS: NA; } \\
\text { BDI: NA; } \\
\text { DIS-III-R: NA }\end{array}$ & $\begin{array}{l}\text { Toddlers with depressed } \\
\text { mothers expressed } \\
\text { significantly more } \\
\text { insecure attachments than } \\
\text { did toddlers with } \\
\text { non-disordered mothers, } \\
\text { and this difference was } \\
\text { not accounted for by } \\
\text { contextual risk. }\end{array}$ & $\begin{array}{c}\text { Adequate sample size } \\
\text { with low attrition rate, } \\
\text { validated methods, clear } \\
\text { methodology and } \\
\text { statistical analysis, direct } \\
\text { measurement of } \\
\text { depression-attachment } \\
\text { influence. No information } \\
\text { about double-blind } \\
\text { procedure or code } \\
\text { experience, no } \\
\text { representative low-risk } \\
\text { study population. }\end{array}$ \\
\hline
\end{tabular}


Table 1. Cont.

\begin{tabular}{|c|c|c|c|c|c|}
\hline $\begin{array}{l}\text { Study (Year), Country } \\
\text { Study Design. }\end{array}$ & $\begin{array}{c}\text { Main Objectives/ } \\
\text { Research Questions }\end{array}$ & $\begin{array}{l}\text { Participant Details/ } \\
\text { Sample Size } \\
\text { N; M Mother's Age } \\
\text { (Standard Deviation, } \\
\text { SD) }\end{array}$ & $\begin{array}{l}\text { Attachment and } \\
\text { Depression } \\
\text { Measurement: Name of } \\
\text { a Tool and the Time } \\
\text { When Administered (in } \\
\text { Trimester if Prenatally or } \\
\text { Months if Postnatally) }\end{array}$ & Results & Study Quality Score \\
\hline $\begin{array}{l}\text { [45] (1992), UK } \\
\text { longitudinal study }\end{array}$ & $\begin{array}{l}\text { To compare the cognitive, } \\
\text { social and emotional } \\
\text { development of infants of } \\
\text { mothers with main } \\
\text { depression and/or } \\
\text { postpartum depression } \\
\text { with that of infants of } \\
\text { non-depressed mothers. } \\
\text { To assess the impact of the } \\
\text { style of interpersonal } \\
\text { contact associated with } \\
\text { depression (rather than } \\
\text { depressive symptoms) on } \\
\text { attachment style. }\end{array}$ & $\begin{array}{l}\text { Mothers of healthy borne } \\
\text { children with major } \\
\text { depression episode and } \\
\text { healthy control group. } \\
\quad N=111 ; \\
(\mathrm{M} \text { age }=28 ; \mathrm{SD}=4.3)\end{array}$ & $\begin{array}{l}\text { SSP: } 18 \text { months; } \\
\text { EPDS: } 6 \text { and } 12 \text { months; } \\
\text { SPI: } 3 \text { month; } \\
\text { SADS-L: } 3 \text { and } 18 \text { months }\end{array}$ & $\begin{array}{l}\text { Infants whose mothers } \\
\text { had been depressed in the } \\
\text { postnatal period were } \\
\text { significantly more likely } \\
\text { to be insecurely attached } \\
\text { to their mothers at } 18 \\
\text { months than infants of } \\
\text { non-depressed mothers. } \\
\text { No difference in outcome } \\
\text { was found between } \\
\text { infants whose mothers } \\
\text { had their first episode of } \\
\text { depression following } \\
\text { childbirth and those who } \\
\text { had previous as well as } \\
\text { postpartum depression. } \\
\text { The duration, severity of } \\
\text { the depression and } \\
\text { current maternal } \\
\text { depression was unrelated } \\
\text { to infant outcome. } \\
\text { Women who had previous } \\
\text { but not postpartum } \\
\text { depression were not } \\
\text { significantly more likely } \\
\text { to have infants who were } \\
\text { insecure than women with } \\
\text { no history of depression. }\end{array}$ & $\begin{array}{c} \\
\text { Representative, albeit } \\
\text { inadequate, sample size } \\
\text { with low attrition rate, } \\
\text { validated methods, and } \\
\text { direct measurement of } \\
\text { depression-attachment } \\
\text { influence. Clear } \\
\text { methodology but vague } \\
\text { statistical analysis and } \\
\text { conclusion are not } \\
\text { consistent. No } \\
\text { information about coder } \\
\text { experience or } \\
\text { double-blind procedure. }\end{array}$ \\
\hline
\end{tabular}

ADS-L-German version of CES-D; AQS—Attachment Behaviour Q-Sort; BDI—Beck Depression Inventory; BSI—Brief Symptom Inventory; CES-D—Center for Epidemiological Studies Depression; CIDI-Composite International Diagnostic Interview; DACL-Depression Adjective Check Lists; EPDS—Edinburgh Postnatal Depression Scale; HRSD-Hamilton Rating Scale for Depression; IDD—Inventory to Diagnose Depression; PCERA-Parent-Child Early Relational Assessment Scale; PSE-Standardized Psychiatric Interview Present State Examination; SADS-L-Schedule for Affective Disorders and Schizophrenia; SCID—Structured Clinical Interview for DSM-IV; SCID-NP—Structured Clinical Interview for DSM-IV-Non-Patient Version; SPI—Standardized Psychiatric Interview; SSP—Strange Situation Procedure; TAS-45—Toddler Attachment Sort—short version of Attachment Q Sort. 
Table 2. Details of the reviewed studies measuring the impact of maternal depression on attachment security; all used self-report questionnaires to diagnose depression.

\begin{tabular}{|c|c|c|c|c|c|}
\hline $\begin{array}{l}\text { Study (Year), Country } \\
\text { Study Design }\end{array}$ & $\begin{array}{c}\text { Main Objectives/ } \\
\text { Research Questions }\end{array}$ & $\begin{array}{l}\text { Participant Details/ } \\
\text { Sample Size } \\
\text { N; M Mother's Age } \\
\text { (Standard Deviation, } \\
\text { SD) }\end{array}$ & $\begin{array}{l}\text { Attachment and } \\
\text { Depression } \\
\text { Measurement: Name of } \\
\text { a Tool and the Time } \\
\text { When Administered (in } \\
\text { Trimester if Prenatally or } \\
\text { Months if Postnatally) }\end{array}$ & Results & Study Quality Score \\
\hline $\begin{array}{l}\text { [53] (2018), USA } \\
\text { longitudinal study }\end{array}$ & $\begin{array}{l}\text { To investigate the } \\
\text { relationships between } \\
\text { maternal depression risk } \\
\text { and mind-mindedness on } \\
\text { infant attachment } \\
\text { behavior at one year. }\end{array}$ & $\begin{array}{c}\text { A varied and } \\
\text { representative sample } \\
\text { with socio-economic } \\
\text { diversity. } \\
N=87 ; \\
\text { (M age = 29.4; } \mathrm{SD}=6.5 \text { ) }\end{array}$ & $\begin{array}{l}\text { SSP: } 12 \text { months; } \\
\text { CES-D: } 6 \text { weeks and } 4 \text { and } \\
12 \text { months }\end{array}$ & $\begin{array}{l}\text { Maternal depression risk } \\
\text { decreased over the infants' } \\
\text { first year, with the } \\
\text { sharpest decline between } \\
6 \text { weeks and } 4 \text { months. } \\
\text { Mothers at risk of } \\
\text { depression when infants } \\
\text { were } 6 \text { weeks showed less } \\
\text { appropriate } \\
\text { mind-mindedness at } 4 \\
\text { months. The degree of } \\
\text { disorganized attachment } \\
\text { behavior by the infants at } \\
\text { one year was positively } \\
\text { associated with the risk of } \\
\text { maternal depression at } 6 \\
\text { weeks, and negatively } \\
\text { associated with maternal } \\
\text { appropriate } \\
\text { mind-mindedness at } 4 \\
\text { months. }\end{array}$ & $\begin{array}{l} \\
\text { Representative but not } \\
\text { adequate sample size with } \\
\text { high attrition rate, } \\
\text { validated methods, clear } \\
\text { methodology and } \\
\text { statistical analysis, direct } \\
\text { measurement of } \\
\text { depression-attachment } \\
\text { influence, double-blind } \\
\text { procedure used by } \\
\text { experienced coders. }\end{array}$ \\
\hline
\end{tabular}


Table 2. Cont.

\begin{tabular}{|c|c|c|c|c|c|}
\hline $\begin{array}{l}\text { Study (Year), Country } \\
\text { Study Design }\end{array}$ & $\begin{array}{c}\text { Main Objectives/ } \\
\text { Research Questions }\end{array}$ & $\begin{array}{l}\text { Participant Details/ } \\
\text { Sample Size } \\
\text { N; M Mother's Age } \\
\text { (Standard Deviation, } \\
\text { SD) }\end{array}$ & $\begin{array}{l}\text { Attachment and } \\
\text { Depression } \\
\text { Measurement: Name of } \\
\text { a Tool and the Time } \\
\text { When Administered (in } \\
\text { Trimester if Prenatally or } \\
\text { Months if Postnatally) }\end{array}$ & Results & Study Quality Score \\
\hline $\begin{array}{l}\text { [42] (2018), Canada } \\
\text { prospective } \\
\text { cross-sectional }\end{array}$ & $\begin{array}{l}\text { To examine the influence } \\
\text { of maternal oxytocin } \\
\text { receptor (OXTR, rs53576) } \\
\text { genotype and cortisol } \\
\text { secretion as moderators of } \\
\text { the relation between } \\
\text { maternal childhood } \\
\text { maltreatment history and } \\
\text { disorganized } \\
\text { mother-infant } \\
\text { attachment. }\end{array}$ & $\begin{array}{l}\text { Mothers from low-risk } \\
\text { sample, mainly } \\
\text { high-educated sample. } \\
\quad N=314 \\
(\mathrm{M} \text { age }=32.9 ; \mathrm{SD}=4.5)\end{array}$ & $\begin{array}{l}\text { SSP: } 17 \text { months; } \\
\text { BDI: } 16 \text { months }\end{array}$ & $\begin{array}{c}\text { Marital status, } \\
\text { employment, age, breast } \\
\text { feeding status, } \\
\text { self-reported ethnicity, } \\
\text { depression, parenting } \\
\text { stress and sensitivity, } \\
\text { family income, number of } \\
\text { siblings and hours per } \\
\text { week in out of home care } \\
\text { was not associated with } \\
\text { attachment } \\
\text { disorganization scores. } \\
\text { Only infant sex was } \\
\text { related to disorganization, } \\
\text { insofar that males had } \\
\text { higher disorganization } \\
\text { scores than females. } \\
\text { Maltreatment history } \\
\text { more strongly predicted } \\
\text { mother-infant attachment } \\
\text { disorganization score and } \\
\text { disorganized classification } \\
\text { for mothers with more } \\
\text { plasticity alleles of OXTR } \\
\text { (G) and for mothers with } \\
\text { higher SSP cortisol } \\
\text { secretion, relative to } \\
\text { mothers with fewer } \\
\text { plasticity alleles and lower } \\
\text { SSP cortisol secretion. }\end{array}$ & $\begin{array}{c} \\
\text { Adequate sample size } \\
\text { with no information about } \\
\text { attrition rate. Validated } \\
\text { methods, used a } \\
\text { double-blind procedure, } \\
\text { clear methodology and } \\
\text { statistical analysis. No } \\
\text { representative low-risk } \\
\text { sample and no direct } \\
\text { measurement of } \\
\text { depression-attachment } \\
\text { influence. }\end{array}$ \\
\hline
\end{tabular}


Table 2. Cont.

\begin{tabular}{|c|c|c|c|c|c|}
\hline $\begin{array}{l}\text { Study (Year), Country } \\
\text { Study Design }\end{array}$ & $\begin{array}{c}\text { Main Objectives/ } \\
\text { Research Questions }\end{array}$ & $\begin{array}{l}\text { Participant Details/ } \\
\text { Sample Size } \\
\text { N; M Mother's Age } \\
\text { (Standard Deviation, } \\
\text { SD) }\end{array}$ & $\begin{array}{l}\text { Attachment and } \\
\text { Depression } \\
\text { Measurement: Name of } \\
\text { a Tool and the Time } \\
\text { When Administered (in } \\
\text { Trimester if Prenatally or } \\
\text { Months if Postnatally) }\end{array}$ & Results & Study Quality Score \\
\hline $\begin{array}{l}\text { [54] (2018), USA } \\
\text { longitudinal study }\end{array}$ & $\begin{array}{c}\text { To examine the } \\
\text { association between } \\
\text { multiple forms of early } \\
\text { adversity-socioeconomic } \\
\text { status disadvantage, } \\
\text { familial stress, maternal } \\
\text { depression, and security } \\
\text { of attachment-and } \\
\text { individual differences in a } \\
\text { composite measure of } \\
\text { pro-inflammatory } \\
\text { cytokines and the acute } \\
\text { phase protein CRP (C } \\
\text { Reactive Protein). }\end{array}$ & $\begin{array}{c}\text { Mothers from } \\
\text { psychosocial and/or } \\
\text { socio-demographic } \\
\text { high-risk groups. } \\
\quad N=49 ; \\
(\mathrm{M} \text { age }=24 ; \mathrm{SD}=4.7)\end{array}$ & $\begin{array}{l}\text { SSP: } 17 \text { months; } \\
\text { CES-D: } 5 \text { and } 17 \text { months }\end{array}$ & $\begin{array}{l}\text { Higher levels of } \\
\text { depressive symptoms and } \\
\text { insecure attachment are } \\
\text { significantly associated } \\
\text { with higher inflammatory } \\
\text { load score (ILS). No } \\
\text { significant association } \\
\text { between maternal } \\
\text { depressive symptoms and } \\
\text { elevated infant ILS was } \\
\text { observed for securely } \\
\text { attached infants, whereas } \\
\text { insecurely attached } \\
\text { infants showed high } \\
\text { levels of ILS at high levels } \\
\text { of maternal depressive } \\
\text { symptoms. Securely } \\
\text { attached infants had the } \\
\text { least amount of salivary } \\
\text { inflammation, regardless } \\
\text { of mothers' levels of } \\
\text { depression. Regions of } \\
\text { significance analysis } \\
\text { indicated that starting at } \\
\text { sub-clinical levels of } \\
\text { maternal depressive } \\
\text { symptoms, infants } \\
\text { classified as insecure had } \\
\text { significantly higher ILS } \\
\text { than all other infants. }\end{array}$ & $\begin{array}{l}\text { No adequate sample size } \\
\text { form high-risk group of } \\
\text { mothers with no } \\
\text { information about } \\
\text { attrition rate. Validated } \\
\text { methods, double-blind } \\
\text { procedure by experienced } \\
\text { coders, clear methodology } \\
\text { and statistical analysis but } \\
\text { with indirect } \\
\text { measurement of } \\
\text { depression-attachment } \\
\text { influence. }\end{array}$ \\
\hline
\end{tabular}


Table 2. Cont.

\begin{tabular}{|c|c|c|c|c|c|}
\hline $\begin{array}{l}\text { Study (Year), Country } \\
\text { Study Design }\end{array}$ & $\begin{array}{c}\text { Main Objectives/ } \\
\text { Research Questions }\end{array}$ & $\begin{array}{l}\text { Participant Details/ } \\
\text { Sample Size } \\
\text { N; M Mother's Age } \\
\text { (Standard Deviation, } \\
\text { SD) }\end{array}$ & $\begin{array}{l}\text { Attachment and } \\
\text { Depression } \\
\text { Measurement: Name of } \\
\text { a Tool and the Time } \\
\text { When Administered (in } \\
\text { Trimester if Prenatally or } \\
\text { Months if Postnatally) }\end{array}$ & Results & Study Quality Score \\
\hline $\begin{array}{l}\text { [55] (2016), USA } \\
\text { longitudinal study }\end{array}$ & $\begin{array}{l}\text { To determine whether the } \\
\text { sex of an infant influences } \\
\text { early vulnerability to } \\
\text { maternal psychosocial } \\
\text { risk, as indexed by } \\
\text { trajectories of maternal } \\
\text { depressive symptoms } \\
\text { across the first } 18 \text { months' } \\
\text { postpartum, and toddlers' } \\
\text { attachment security at } 18 \\
\text { months of age. }\end{array}$ & $\begin{array}{c}\text { African American } \\
\text { mothers from } \\
\text { heterogeneous } \\
\text { socio-economic } \\
\text { backgrounds. } \\
N=182 ; \\
(\mathrm{M} \text { age }=29.5 ; \mathrm{SD}=4.37)\end{array}$ & $\begin{array}{l}\text { SSP: } 18 \text { months; } \\
\text { CES-D: } 2 \text { and } 3 \text { and } 6 \text { and } \\
12 \text { and } 18 \text { months }\end{array}$ & $\begin{array}{c}\text { Toddlers' attachment } \\
\text { security was significantly } \\
\text { and negatively correlated } \\
\text { with maternal depressive } \\
\text { symptoms at } 2,3 \text { and } 6 \\
\text { months, marginally } \\
\text { associated with symptoms } \\
\text { at } 12 \text { months, but not } \\
\text { associated with maternal } \\
\text { depressive symptoms at } \\
18 \text { months. Boys' } \\
\text { attachment security was } \\
\text { significantly and } \\
\text { negatively associated with } \\
\text { maternal depressive } \\
\text { symptoms during the first } \\
\text { postpartum year (at } 2,3,6, \\
\text { and } 12 \text { months). Girls' } \\
\text { attachment security was } \\
\text { not significantly } \\
\text { associated with maternal } \\
\text { depressive symptoms at } \\
\text { any time of measurement. }\end{array}$ & $\begin{array}{c} \\
\text { Adequate sample size, } \\
\text { low attrition rate, } \\
\text { validated methods, clear } \\
\text { statistical analysis and } \\
\text { direct measurement of } \\
\text { depression-attachment } \\
\text { influence; double-blind } \\
\text { procedure used by } \\
\text { experienced coders. } \\
\text { Representative African } \\
\text { American population. }\end{array}$ \\
\hline
\end{tabular}


Table 2. Cont.

\begin{tabular}{|c|c|c|c|c|c|}
\hline $\begin{array}{l}\text { Study (Year), Country } \\
\text { Study Design }\end{array}$ & $\begin{array}{c}\text { Main Objectives/ } \\
\text { Research Questions }\end{array}$ & $\begin{array}{l}\text { Participant Details/ } \\
\text { Sample Size } \\
\text { N; M Mother's Age } \\
\text { (Standard Deviation, } \\
\text { SD) }\end{array}$ & $\begin{array}{l}\text { Attachment and } \\
\text { Depression } \\
\text { Measurement: Name of } \\
\text { a Tool and the Time } \\
\text { When Administered (in } \\
\text { Trimester if Prenatally or } \\
\text { Months if Postnatally) }\end{array}$ & Results & Study Quality Score \\
\hline $\begin{array}{l}\text { [56] (2014), Italy } \\
\text { longitudinal study }\end{array}$ & $\begin{array}{c}\text { To examine the predictors } \\
\text { of mother-child } \\
\text { interaction quality and } \\
\text { child attachment security } \\
\text { in a sample of first-time } \\
\text { mothers with } \\
\text { psychosocial and/or } \\
\text { socio-demographic risk } \\
\text { factors. }\end{array}$ & $\begin{array}{c}\text { Mothers from } \\
\text { psychosocial and/or } \\
\text { socio-demographic } \\
\text { high-risk groups. } \\
N=40 ; \\
(\mathrm{M} \text { age }=27.3 ; \mathrm{SD}=6.56)\end{array}$ & $\begin{array}{l}\text { AQS: } 18 \text { months; } \\
\text { SCL-90-R: } 3 \text { months; } \\
\text { EPDS: } 3 \text { and } 6 \text { months }\end{array}$ & $\begin{array}{l}\text { Attachment security was } \\
\text { not significantly } \\
\text { associated with young } \\
\text { maternal age, single } \\
\text { parenting, } \\
\text { psychopathological } \\
\text { symptoms or low family } \\
\text { socio-economic status. } \\
\text { When groups were } \\
\text { divided according to risk } \\
\text { factors } \\
\text { (socio-demographic only, } \\
\text { psychosocial only, both } \\
\text { factors) only } \\
\text { socio-demographic factors } \\
\text { were significantly } \\
\text { associated with } \\
\text { attachment security. } \\
\text { Postpartum depression } \\
\text { showed no association } \\
\text { with either mother-child } \\
\text { emotional availability or } \\
\text { child attachment security. }\end{array}$ & $\begin{array}{l}\text { No representative and no } \\
\text { adequate sample size, } \\
\text { with no direct } \\
\text { measurement of } \\
\text { depression-attachment } \\
\text { influence. Unclear } \\
\text { methodology and } \\
\text { statistical analysis. } \\
\text { Validated methods, SSP } \\
\text { procedure performed by } \\
\text { experienced coders but no } \\
\text { information about } \\
\text { double-blind procedure. } \\
\text { Low attrition rate. }\end{array}$ \\
\hline
\end{tabular}


Table 2. Cont

\begin{tabular}{|c|c|c|c|c|c|}
\hline $\begin{array}{l}\text { Study (Year), Country } \\
\text { Study Design }\end{array}$ & $\begin{array}{c}\text { Main Objectives/ } \\
\text { Research Questions }\end{array}$ & $\begin{array}{l}\text { Participant Details/ } \\
\text { Sample Size } \\
\text { N; M Mother's Age } \\
\text { (Standard Deviation, } \\
\text { SD) }\end{array}$ & $\begin{array}{l}\text { Attachment and } \\
\text { Depression } \\
\text { Measurement: Name of } \\
\text { a Tool and the Time } \\
\text { When Administered (in } \\
\text { Trimester if Prenatally or } \\
\text { Months if Postnatally) }\end{array}$ & Results & Study Quality Score \\
\hline $\begin{array}{c}\text { [39] (2014), USA } \\
\text { prospective } \\
\text { cross-sectional study }\end{array}$ & $\begin{array}{l}\text { To examine the extent to } \\
\text { which maternal borderline } \\
\text { personality pathology and } \\
\text { related emotional } \\
\text { dysfunction (including } \\
\text { emotion regulation } \\
\text { difficulties and emotional } \\
\text { intensity/reactivity) are } \\
\text { connected with infant } \\
\text { emotional regulation } \\
\text { difficulties. To examine } \\
\text { the moderating role of } \\
\text { mother-infant attachment } \\
\text { in the relations between } \\
\text { maternal borderline } \\
\text { personality pathology and } \\
\text { related emotional } \\
\text { dysfunction and infant } \\
\text { emotional regulation. }\end{array}$ & $\begin{array}{l}\text { Mothers with borderline } \\
\text { personality disorder. } \\
\qquad N=101 ; \\
(\mathrm{M} \text { age }=28.7 ; \mathrm{SD}=5.6)\end{array}$ & $\begin{array}{c}\text { SSP: between } 12 \text { and } 23 \\
\text { months; } \\
\text { DASS: } 12 \text { months }\end{array}$ & $\begin{array}{l}\text { High scores in the } \\
\text { depression subscale of } \\
\text { DASS correlated } \\
\text { positively with a high } \\
\text { symptomatology of the } \\
\text { borderline personality } \\
\text { (BP). No link was found } \\
\text { between depressive } \\
\text { symptoms and } \\
\text { attachment classification. } \\
\text { Results suggest that it } \\
\text { may be the emotional } \\
\text { dysfunction associated } \\
\text { with BP, rather than the } \\
\text { presence of clinically } \\
\text { relevant BP pathology per } \\
\text { se, that places infants of } \\
\text { mothers with BP } \\
\text { pathology at risk of } \\
\text { negative outcomes. }\end{array}$ & $\begin{array}{l}\text { No adequate sample size } \\
\text { for high-risk group of } \\
\text { mothers with low attrition } \\
\text { rate. Validated methods, } \\
\text { double-blind procedure } \\
\text { used by experienced } \\
\text { coders, clear methodology } \\
\text { and statistical analysis but } \\
\text { indirect measurement of } \\
\text { depression-attachment } \\
\text { influence. }\end{array}$ \\
\hline
\end{tabular}


Table 2. Cont

\begin{tabular}{|c|c|c|c|c|c|}
\hline $\begin{array}{l}\text { Study (Year), Country } \\
\text { Study Design }\end{array}$ & $\begin{array}{c}\text { Main Objectives/ } \\
\text { Research Questions }\end{array}$ & $\begin{array}{l}\text { Participant Details/ } \\
\text { Sample Size } \\
\text { N; M Mother's Age } \\
\text { (Standard Deviation, } \\
\text { SD) }\end{array}$ & $\begin{array}{l}\text { Attachment and } \\
\text { Depression } \\
\text { Measurement: Name of } \\
\text { a Tool and the Time } \\
\text { When Administered (in } \\
\text { Trimester if Prenatally or } \\
\text { Months if Postnatally) }\end{array}$ & Results & Study Quality Score \\
\hline $\begin{array}{l}\text { [57] (2011), Germany } \\
\text { longitudinal study }\end{array}$ & $\begin{array}{l}\text { To examine the effect of } \\
\text { the time of first meeting } \\
\text { between mother and very } \\
\text { low birth weight (VLBW) } \\
\text { newborn on the } \\
\text { establishment of a secure } \\
\text { attachment behavior; to } \\
\text { indicate the role of } \\
\text { maternal depression, } \\
\text { social support and } \\
\text { pregnancy history. }\end{array}$ & $\begin{array}{l}\text { Mothers of very low birth } \\
\text { weight (VLBW) newborns. } \\
\qquad N=52 ; \\
(\mathrm{M} \text { age }=31.2 ; \mathrm{SD}=5.1)\end{array}$ & $\begin{array}{l}\text { SSP: } 12-18 \text { months c.a. } \\
\text { (corrected age); } \\
\text { ADS-L: } 0 \text { and } 3 \text { and } 12 \\
\text { months c.a. }\end{array}$ & $\begin{array}{l}\text { Not seeing child within } 30 \\
\text { min to } 3 \text { h after birth and } \\
\text { first born child were } \\
\text { identified as the best } \\
\text { predictors for insecure } \\
\text { attachment behavior. } \\
\text { Maternal factors including } \\
\text { age of the mother, degree } \\
\text { of depression at three time } \\
\text { points, social support, } \\
\text { social status of mother } \\
\text { and father, and pregnancy } \\
\text { history did not } \\
\text { significantly differ } \\
\text { between children with } \\
\text { secure and insecure } \\
\text { attachment. }\end{array}$ & $\begin{array}{c} \\
\text { No representative or } \\
\text { adequate sample size with } \\
\text { good attrition rate. } \\
\text { Validated methods, used } \\
\text { double-blind procedure, } \\
\text { clear methodology and } \\
\text { statistical analysis, direct } \\
\text { measurement of } \\
\text { depression-attachment } \\
\text { influence. No information } \\
\text { about SSP coder } \\
\text { experience. }\end{array}$ \\
\hline $\begin{array}{l}\text { [58] (2010), UK } \\
\text { longitudinal study }\end{array}$ & $\begin{array}{l}\text { To determine whether } \\
\text { prenatal cortisol exposure } \\
\text { predicts infant cognitive } \\
\text { development and to } \\
\text { evaluate how } \\
\text { infant-parent relationship } \\
\text { moderates this effect. }\end{array}$ & $\begin{array}{c}\text { A varied and } \\
\text { representative sample } \\
\text { with socio-economic } \\
\text { diversity. } \\
N=125 ; \\
(\mathrm{M} \text { age }=36.6 ; \mathrm{SD}=4.1)\end{array}$ & $\begin{array}{l}\text { SSP: } 17 \text { months; } \\
\text { EPDS: } 17 \text { months }\end{array}$ & $\begin{array}{l}\text { Cortisol level during } \\
\text { pregnancy and postnatal } \\
\text { depression were not } \\
\text { associated with infant } \\
\text { attachment style. Securely } \\
\text { attached children had } \\
\text { mothers who reported } \\
\text { lower levels of postnatal } \\
\text { state anxiety. }\end{array}$ & $\begin{array}{l}\text { Adequate and } \\
\text { representative sample } \\
\text { size, validated methods, } \\
\text { clear statistical analysis, } \\
\text { double-blind procedure } \\
\text { used by experienced } \\
\text { coders. High attrition rate } \\
\text { and indirect measurement } \\
\text { of depression-attachment } \\
\text { influence. }\end{array}$ \\
\hline
\end{tabular}


Table 2. Cont

\begin{tabular}{|c|c|c|c|c|c|}
\hline $\begin{array}{l}\text { Study (Year), Country } \\
\text { Study Design }\end{array}$ & $\begin{array}{c}\text { Main Objectives/ } \\
\text { Research Questions }\end{array}$ & $\begin{array}{l}\text { Participant Details/ } \\
\text { Sample Size } \\
\text { N; M Mother's Age } \\
\text { (Standard Deviation, } \\
\text { SD) }\end{array}$ & $\begin{array}{l}\text { Attachment and } \\
\text { Depression } \\
\text { Measurement: Name of } \\
\text { a Tool and the Time } \\
\text { When Administered (in } \\
\text { Trimester if Prenatally or } \\
\text { Months if Postnatally) }\end{array}$ & Results & Study Quality Score \\
\hline $\begin{array}{l}\text { [59] (2009), USA } \\
\text { longitudinal study }\end{array}$ & $\begin{array}{l}\text { To examine the } \\
\text { associations between } \\
\text { household food security } \\
\text { (access to sufficient, safe, } \\
\text { and nutritious food) } \\
\text { during infancy and } \\
\text { attachment and mental } \\
\text { proficiency in } \\
\text { toddlerhood. }\end{array}$ & $\begin{array}{c}\text { A varied and } \\
\text { representative sample } \\
\text { with socio-economic } \\
\text { diversity. } \\
N=7894 ; \\
\text { (M age }=27.3 ; \mathrm{SD}=13.1 \text { ) }\end{array}$ & $\begin{array}{l}\text { TAS-45: } 24 \text { months; } \\
\text { CES-D: } 9 \text { months }\end{array}$ & $\begin{array}{l}\text { Food insecurity has no } \\
\text { significant direct } \\
\text { association with being } \\
\text { insecurely attached. } \\
\text { Instead, food insecurity } \\
\text { works indirectly through } \\
\text { depression and parenting } \\
\text { practices to influence } \\
\text { insecure attachment. } \\
\text { Attachment insecurity is } \\
\text { positively associated with } \\
\text { depression. }\end{array}$ & $\begin{array}{c} \\
\text { Adequate and } \\
\text { representative sample } \\
\text { size, low attrition rate, } \\
\text { validated methods, clear } \\
\text { statistical analysis and } \\
\text { direct measurement of } \\
\text { depression-attachment } \\
\text { influence. No information } \\
\text { about double-blind } \\
\text { procedure and coders } \\
\text { experience. }\end{array}$ \\
\hline
\end{tabular}


Table 2. Cont.

\begin{tabular}{|c|c|c|c|c|c|}
\hline $\begin{array}{l}\text { Study (Year), Country } \\
\text { Study Design }\end{array}$ & $\begin{array}{c}\text { Main Objectives/ } \\
\text { Research Questions }\end{array}$ & $\begin{array}{l}\text { Participant Details/ } \\
\text { Sample Size } \\
\text { N; M Mother's Age } \\
\text { (Standard Deviation, } \\
\text { SD) }\end{array}$ & $\begin{array}{l}\text { Attachment and } \\
\text { Depression } \\
\text { Measurement: Name of } \\
\text { a Tool and the Time } \\
\text { When Administered (in } \\
\text { Trimester if Prenatally or } \\
\text { Months if Postnatally) }\end{array}$ & Results & Study Quality Score \\
\hline $\begin{array}{l}\text { [60] (2005), Canada } \\
\text { longitudinal study }\end{array}$ & $\begin{array}{l}\text { To replicate the finding } \\
\text { that a significant } \\
\text { association exists between } \\
\text { maternal state of mind, } \\
\text { maternal sensitivity, and } \\
\text { infant attachment security, } \\
\text { but also that maternal } \\
\text { sensitivity only partially } \\
\text { mediates the association } \\
\text { between maternal state of } \\
\text { mind and infant } \\
\text { attachment. The second } \\
\text { objective was to consider } \\
\text { whether paths to infant } \\
\text { attachment security may } \\
\text { exist that do not originate } \\
\text { with maternal state of } \\
\text { mind. }\end{array}$ & $\begin{array}{c}\text { Adolescent mothers up to } \\
19 \text { years old. } \\
N=64 ; \\
(\mathrm{M} \text { age }=17.4 ; \mathrm{SD}=1.5)\end{array}$ & $\begin{array}{l}\text { AQS: } 15 \text { and } 18 \text { months; } \\
\text { CES-D: } 6 \text { months }\end{array}$ & $\begin{array}{l}\text { Significant (but weak) } \\
\text { associations were } \\
\text { documented between } \\
\text { maternal attachment state } \\
\text { of mind and maternal } \\
\text { sensitivity, as well as } \\
\text { between maternal } \\
\text { sensitivity and infant } \\
\text { security. Association } \\
\text { between maternal } \\
\text { sensitivity and attachment } \\
\text { security remained } \\
\text { significant even when } \\
\text { other variables were } \\
\text { statistically controlled. A } \\
\text { marginal link was } \\
\text { observed between } \\
\text { maternal depression and } \\
\text { infant attachment security. } \\
\text { Furthermore, there was } \\
\text { no association between } \\
\text { depression and maternal } \\
\text { sensitivity. }\end{array}$ & $\begin{array}{l}\text { Adequate sample size } \\
\text { with no information about } \\
\text { attrition rate. Validated } \\
\text { methods used by } \\
\text { experienced coders, clear } \\
\text { methodology and } \\
\text { statistical analysis and } \\
\text { direct measurement of } \\
\text { depression-attachment } \\
\text { influence. No information } \\
\text { about double-blind } \\
\text { procedure and no } \\
\text { representative group of } \\
\text { adolescent mothers. }\end{array}$ \\
\hline
\end{tabular}


Table 2. Cont

\begin{tabular}{|c|c|c|c|c|c|}
\hline $\begin{array}{l}\text { Study (Year), Country } \\
\text { Study Design }\end{array}$ & $\begin{array}{l}\text { Main Objectives/ } \\
\text { Research Questions }\end{array}$ & $\begin{array}{l}\text { Participant Details/ } \\
\text { Sample Size } \\
\text { N; M Mother's Age } \\
\text { (Standard Deviation, } \\
\text { SD) }\end{array}$ & $\begin{array}{l}\text { Attachment and } \\
\text { Depression } \\
\text { Measurement: Name of } \\
\text { a Tool and the Time } \\
\text { When Administered (in } \\
\text { Trimester if Prenatally or } \\
\text { Months if Postnatally) }\end{array}$ & Results & Study Quality Score \\
\hline $\begin{array}{l}\text { [61] (2002), Israel } \\
\text { longitudinal study }\end{array}$ & $\begin{array}{l}\text { To predict attachment } \\
\text { classifications from: (a) } \\
\text { relevant control variables } \\
\text { (socio-economic status, } \\
\text { marital relation, } \\
\text { knowledge of infant } \\
\text { development), (b) a } \\
\text { maternal variable } \\
\text { (sensitivity or depression) } \\
\text { or child variable (gender } \\
\text { or temperament), (c) a } \\
\text { childcare variable (type of } \\
\text { care at } 12 \text { months, amount } \\
\text { of nonmaternal care, age } \\
\text { of entry into nonmaternal } \\
\text { care, stability of care, } \\
\text { different types of care, } \\
\text { and infant-adult ratio), } \\
\text { and (d) the interaction } \\
\text { between the two selected } \\
\text { (mother/child and } \\
\text { child-care) variables. }\end{array}$ & $\begin{array}{l}\text { Jewish mothers of healthy } \\
\text { children with } \\
\text { socio-economic diversity. } \\
\quad N=758 ; \\
(\mathrm{M} \text { age }=29.2 ; \mathrm{SD}=4.78)\end{array}$ & $\begin{array}{l}\text { SSP: } 12 \text { months; } \\
\text { DACL: } 6 \text { and } 12 \text { months; } \\
\text { BDI: } 6 \text { months }\end{array}$ & $\begin{array}{l}\text { Center-care adversely } \\
\text { increased the likelihood of } \\
\text { infants developing } \\
\text { insecure attachment to } \\
\text { their mothers as } \\
\text { compared to infants who } \\
\text { were either in maternal } \\
\text { care, individual } \\
\text { non-parental care with a } \\
\text { relative, individual } \\
\text { nonparental care with a } \\
\text { paid caregiver, or family } \\
\text { day-care. Mothers found } \\
\text { to be more sensitive were } \\
\text { more likely to have } \\
\text { securely attached infants } \\
\text { regardless of care type } \\
\text { (maternal, family, nanny } \\
\text { etc.). Maternal depression, } \\
\text { child's gender, } \\
\text { temperament, age (in } \\
\text { weeks) when nonmaternal } \\
\text { care was introduced, } \\
\text { length of extra care (3-12 } \\
\text { months), stability of care } \\
\text { were not found to be } \\
\text { significant predictors of } \\
\text { attachment } \\
\text { security/insecurity. }\end{array}$ & $\begin{array}{c} \\
\text { Adequate and } \\
\text { representative sample } \\
\text { size, low attrition rate, } \\
\text { validated methods, clear } \\
\text { statistical analysis and } \\
\text { direct measurement of } \\
\text { depression-attachment } \\
\text { influence, double-blind } \\
\text { procedure used by } \\
\text { experienced coders. }\end{array}$ \\
\hline
\end{tabular}


Table 2. Cont

\begin{tabular}{|c|c|c|c|c|c|}
\hline $\begin{array}{l}\text { Study (Year), Country } \\
\text { Study Design }\end{array}$ & $\begin{array}{c}\text { Main Objectives/ } \\
\text { Research Questions }\end{array}$ & $\begin{array}{l}\text { Participant Details/ } \\
\text { Sample Size } \\
\text { N; M Mother's Age } \\
\text { (Standard Deviation, } \\
\text { SD) }\end{array}$ & $\begin{array}{l}\text { Attachment and } \\
\text { Depression } \\
\text { Measurement: Name of } \\
\text { a Tool and the Time } \\
\text { When Administered (in } \\
\text { Trimester if Prenatally or } \\
\text { Months if Postnatally) }\end{array}$ & Results & Study Quality Score \\
\hline $\begin{array}{l}\text { [62] (2001), Sweden } \\
\text { longitudinal study }\end{array}$ & $\begin{array}{l}\text { To explore the long-term } \\
\text { impact of depressive } \\
\text { symptomatology on } \\
\text { mother-child interaction } \\
\text { and on infant attachment } \\
\text { to mothers. }\end{array}$ & $\begin{array}{l}\text { No adequate information } \\
\text { about studied sample. } \\
\qquad N=45 ; \\
(\mathrm{M} \text { age = NA, SD = NA) }\end{array}$ & $\begin{array}{l}\text { PCERA: } 15 \text { and } 18 \text { months; } \\
\text { EPDS: } 2 \text { months }\end{array}$ & $\begin{array}{l}\text { Children of mothers with } \\
\text { high EPDS scores were } \\
\text { less curious and focused } \\
\text { on free play situations } \\
\text { than children of low EPDS } \\
\text { scorers. Even if the } \\
\text { proportion of insecurely } \\
\text { attached children did not } \\
\text { differ between high and } \\
\text { low EPDS groups, those } \\
\text { children who had mothers } \\
\text { in the high-scoring group } \\
\text { were more likely to show } \\
\text { restricted levels of joy in } \\
\text { their secure attachment } \\
\text { behaviours. }\end{array}$ & $\begin{array}{c} \\
\text { No adequate sample size } \\
\text { with high attrition rate. } \\
\text { Validated methods, clear } \\
\text { methodology and } \\
\text { statistical analysis, direct } \\
\text { measurement of } \\
\text { depression-attachment } \\
\text { influence, double-blind } \\
\text { procedure used by } \\
\text { experienced coders. No } \\
\text { clear information whether } \\
\text { study population is } \\
\text { representative. }\end{array}$ \\
\hline
\end{tabular}


Table 2. Cont

\begin{tabular}{|c|c|c|c|c|c|}
\hline $\begin{array}{l}\text { Study (Year), Country } \\
\text { Study Design }\end{array}$ & $\begin{array}{c}\text { Main Objectives/ } \\
\text { Research Questions }\end{array}$ & $\begin{array}{l}\text { Participant Details/ } \\
\text { Sample Size } \\
\text { N; M Mother's Age } \\
\text { (Standard Deviation, } \\
\text { SD) }\end{array}$ & $\begin{array}{l}\text { Attachment and } \\
\text { Depression } \\
\text { Measurement: Name of } \\
\text { a Tool and the Time } \\
\text { When Administered (in } \\
\text { Trimester if Prenatally or } \\
\text { Months if Postnatally) }\end{array}$ & Results & Study Quality Score \\
\hline $\begin{array}{l}\text { [63] (2001), UK } \\
\text { longitudinal study }\end{array}$ & $\begin{array}{l}\text { To determine whether } \\
\text { experience of loss may } \\
\text { lead to unresolved state of } \\
\text { mind in a mother, and } \\
\text { whether this is associated } \\
\text { with increasing rates of } \\
\text { disorganization of infant } \\
\text { attachment patterns } \\
\text { among infants born } \\
\text { subsequent to stillbirth. } \\
\text { To determine whether } \\
\text { disorganized infant } \\
\text { attachment could be } \\
\text { predicted by maternal } \\
\text { symptoms of depression } \\
\text { or anxiety, by social } \\
\text { disadvantage, by } \\
\text { additional experience of } \\
\text { miscarriage or } \\
\text { termination of pregnancy, } \\
\text { or by whether or not the } \\
\text { mother had seen and held } \\
\text { her stillborn infant and } \\
\text { had held a funeral for the } \\
\text { infant. }\end{array}$ & $\begin{array}{l}\text { Mothers who have } \\
\text { experienced a stillbirth } \\
\text { (after } 18 \text { month of } \\
\text { gestation) before their } \\
\text { current pregnancy and a } \\
\text { control group. } \\
\quad N=106 ; \\
\text { (M age }=19.9 ; \mathrm{SD}=5.4)\end{array}$ & $\begin{array}{c}\text { SSP: } 12 \text { months; } \\
\text { EPDS: 3rd trimester and } 6 \\
\text { weeks; } \\
\text { BDI: } 26 \text { weeks and } \\
12 \text { months }\end{array}$ & $\begin{array}{l}\text { Infants next-born after a } \\
\text { stillbirth were } \\
\text { significantly more likely } \\
\text { to have disorganized } \\
\text { attachment style than } \\
\text { control infants. Maternal } \\
\text { depression was not } \\
\text { associated with child } \\
\text { attachment style. }\end{array}$ & $\begin{array}{c} \\
\text { Adequate and } \\
\text { representative sample } \\
\text { size, validated methods, } \\
\text { clear statistical analysis } \\
\text { and direct measurement } \\
\text { of depression-attachment } \\
\text { influence, double-blind } \\
\text { procedure used by } \\
\text { experienced coders. High } \\
\text { attrition rate. }\end{array}$ \\
\hline
\end{tabular}


Table 2. Cont

\begin{tabular}{|c|c|c|c|c|c|}
\hline $\begin{array}{l}\text { Study (Year), Country } \\
\text { Study Design }\end{array}$ & $\begin{array}{c}\text { Main Objectives/ } \\
\text { Research Questions }\end{array}$ & $\begin{array}{l}\text { Participant Details/ } \\
\text { Sample Size } \\
\text { N; M Mother's Age } \\
\text { (Standard Deviation, } \\
\text { SD) }\end{array}$ & $\begin{array}{c}\text { Attachment and } \\
\text { Depression } \\
\text { Measurement: Name of } \\
\text { a Tool and the Time } \\
\text { When Administered (in } \\
\text { Trimester if Prenatally or } \\
\text { Months if Postnatally) }\end{array}$ & Results & Study Quality Score \\
\hline $\begin{array}{l}\text { [64] (2000), USA } \\
\text { longitudinal study }\end{array}$ & $\begin{array}{l}\text { To explore the effects of } \\
\text { marital separation and } \\
\text { divorce on psychological } \\
\text { development of children } \\
\text { in the first } 3 \text { years of life. } \\
\text { To examine the } \\
\text { consequences of marital } \\
\text { separation on children's } \\
\text { functioning immediately } \\
\text { after separation and to } \\
\text { assess whether maternal } \\
\text { background before and } \\
\text { after marital separation } \\
\text { may affect studied } \\
\text { variables. }\end{array}$ & $\begin{array}{c}\text { A varied and } \\
\text { representative sample } \\
\text { with socio-economic } \\
\text { diversity. } \\
N=340 ; \\
(\mathrm{M} \text { age }=26.3 ; \mathrm{SD}=\mathrm{NA})\end{array}$ & $\begin{array}{l}\text { SSP: } 15 \text { and } 36 \text { months; } \\
\text { AQS: } 24 \text { months; } \\
\text { CES-D: } 1 \text { and } 6 \text { and } 15 \\
\text { and } 24 \text { and } 36 \text { months }\end{array}$ & $\begin{array}{l}\text { Children in 2-parent } \\
\text { families performed better } \\
\text { than children in 1-parent } \\
\text { families on assessments of } \\
\text { cognitive and social } \\
\text { abilities, problem } \\
\text { behavior, attachment } \\
\text { security, and behavior } \\
\text { with mother. However, } \\
\text { controlling for maternal } \\
\text { education and family } \\
\text { income reduced these } \\
\text { differences, and } \\
\text { associations with } \\
\text { separated-intact marital } \\
\text { status were } \\
\text { non-significant. Hence, } \\
\text { child psychological } \\
\text { development was not } \\
\text { affected by parental } \\
\text { separation per se; it was } \\
\text { related to maternal } \\
\text { income, education, } \\
\text { ethnicity, child- rearing } \\
\text { beliefs, depressive } \\
\text { symptoms, and behavior. } \\
\text { Maternal depression } \\
\text { increased behavioral } \\
\text { problems of the child, but } \\
\text { did not affect the security } \\
\text { of attachment style. }\end{array}$ & $\begin{array}{c} \\
\text { Adequate and } \\
\text { representative sample } \\
\text { size, low attrition rate, } \\
\text { validated methods, clear } \\
\text { statistical analysis and } \\
\text { direct measurement of } \\
\text { depression-attachment } \\
\text { influence, SSP procedure } \\
\text { performed by experienced } \\
\text { coders. No information } \\
\text { about double-blind } \\
\text { procedure. }\end{array}$ \\
\hline
\end{tabular}


Table 2. Cont

\begin{tabular}{|c|c|c|c|c|c|}
\hline $\begin{array}{l}\text { Study (Year), Country } \\
\text { Study Design }\end{array}$ & $\begin{array}{c}\text { Main Objectives/ } \\
\text { Research Questions }\end{array}$ & $\begin{array}{l}\text { Participant Details/ } \\
\text { Sample Size } \\
\text { N; M Mother's Age } \\
\text { (Standard Deviation, } \\
\text { SD) }\end{array}$ & $\begin{array}{l}\text { Attachment and } \\
\text { Depression } \\
\text { Measurement: Name of } \\
\text { a Tool and the Time } \\
\text { When Administered (in } \\
\text { Trimester if Prenatally or } \\
\text { Months if Postnatally) }\end{array}$ & Results & Study Quality Score \\
\hline $\begin{array}{c}\text { [35] (1990), USA } \\
\text { Intervention longitudinal } \\
\text { study }\end{array}$ & $\begin{array}{l}\text { To assess whether a family } \\
\text { in high-risk circumstances } \\
\text { (combined effects of } \\
\text { poverty, maternal } \\
\text { depression, and } \\
\text { caretaking inadequacy) } \\
\text { could benefit from family } \\
\text { support services. }\end{array}$ & $\begin{array}{c}\text { Mothers from a high-risk } \\
\text { (low income) group and } \\
\text { controls. } \\
N=76 ; \\
(\mathrm{M} \text { age = } 24.06, \mathrm{SD}=\mathrm{NA})\end{array}$ & $\begin{array}{l}\text { SSP: } 12 \text { months; } \\
\text { CES-D: } 12 \text { and } 18 \text { months }\end{array}$ & $\begin{array}{l}\text { The negative effects of } \\
\text { social risk status were } \\
\text { more pervasive in regard } \\
\text { to infant attachment } \\
\text { security than in regard to } \\
\text { mental development, with } \\
\text { the unsupported high-risk } \\
\text { group as a whole differing } \\
\text { significantly both from the } \\
\text { supported high-risk } \\
\text { group. Unsupported } \\
\text { high-risk infants had a } \\
\text { very high rate of } \\
\text { insecure-disorganized } \\
\text { attachment, } 60 \% \text {, } \\
\text { compared to } 29 \% \text { for } \\
\text { high-risk infants } \\
\text { supported by family } \\
\text { services and } 28 \% \text { for } \\
\text { community infants. }\end{array}$ & $\begin{array}{c} \\
\text { Representative but not } \\
\text { adequate sample size with } \\
\text { no information about } \\
\text { attrition rate. Validated } \\
\text { methods, double-blind } \\
\text { procedure used by } \\
\text { experienced coders, clear } \\
\text { methodology and } \\
\text { statistical analysis, no } \\
\text { direct measurement of } \\
\text { depression-attachment } \\
\text { influence. }\end{array}$ \\
\hline
\end{tabular}


Table 2. Cont.

\begin{tabular}{|c|c|c|c|c|c|}
\hline $\begin{array}{l}\text { Study (Year), Country } \\
\text { Study Design }\end{array}$ & $\begin{array}{c}\text { Main Objectives/ } \\
\text { Research Questions }\end{array}$ & $\begin{array}{l}\text { Participant Details/ } \\
\text { Sample Size } \\
\text { N; M Mother's Age } \\
\text { (Standard Deviation, } \\
\text { SD) }\end{array}$ & $\begin{array}{l}\text { Attachment and } \\
\text { Depression } \\
\text { Measurement: Name of } \\
\text { a Tool and the Time } \\
\text { When Administered (in } \\
\text { Trimester if Prenatally or } \\
\text { Months if Postnatally) }\end{array}$ & Results & Study Quality Score \\
\hline $\begin{array}{l}\text { [65] (1989), USA } \\
\text { longitudinal study }\end{array}$ & $\begin{array}{l}\text { To examine the predictors } \\
\text { of mother-child } \\
\text { interaction quality and } \\
\text { child attachment security } \\
\text { in a sample of first-time } \\
\text { mothers with } \\
\text { psychosocial and/or } \\
\text { socio-demographic risk } \\
\text { factors. }\end{array}$ & $\begin{array}{c}\text { Married mothers. } \\
\quad N=40 ; \\
(\mathrm{M} \text { age }=27.3 ; \mathrm{SD}=6.56)\end{array}$ & $\begin{array}{l}\text { SSP: } 16 \text { and } 40 \text { months; } \\
\text { BDI: } 5 \text { and } 16 \text { months }\end{array}$ & $\begin{array}{l}\text { Insecure infant } \\
\text { attachment at } 16 \text { months } \\
\text { was associated with } \\
\text { maternal perception of } \\
\text { overcontrol, depressed } \\
\text { mood state, and aversive } \\
\text { conditioning to } \\
\text { impending cries in a } \\
\text { laboratory task at the } \\
\text { 5-month period. Mothers } \\
\text { of insecurely-attached } \\
\text { infants were more } \\
\text { depressed at } 5 \text { (but not 16) } \\
\text { months than mothers of } \\
\text { securely attached infants. }\end{array}$ & $\begin{array}{l} \\
\text { No adequate sample size } \\
\text { with low attrition rate. } \\
\text { Validated methods, clear } \\
\text { methodology and } \\
\text { statistical analysis, direct } \\
\text { measurement of } \\
\text { depression-attachment } \\
\text { influence, double-blind } \\
\text { procedure by experienced } \\
\text { coders used. No clear } \\
\text { information whether } \\
\text { study population was } \\
\text { representative. }\end{array}$ \\
\hline
\end{tabular}


Table 2. Cont.

\begin{tabular}{|c|c|c|c|c|c|}
\hline $\begin{array}{l}\text { Study (Year), Country } \\
\text { Study Design }\end{array}$ & $\begin{array}{c}\text { Main Objectives/ } \\
\text { Research Questions }\end{array}$ & $\begin{array}{l}\text { Participant Details/ } \\
\text { Sample Size } \\
\text { N; M Mother's Age } \\
\text { (Standard Deviation, } \\
\text { SD) }\end{array}$ & $\begin{array}{l}\text { Attachment and } \\
\text { Depression } \\
\text { Measurement: Name of } \\
\text { a Tool and the Time } \\
\text { When Administered (in } \\
\text { Trimester if Prenatally or } \\
\text { Months if Postnatally) }\end{array}$ & Results & Study Quality Score \\
\hline $\begin{array}{c}\text { [43] (1986), USA } \\
\text { prospective cross sectional }\end{array}$ & $\begin{array}{l}\text { To examine whether } \\
\text { maternal depression is a } \\
\text { risk factor for infant } \\
\text { development, as well as } \\
\text { for childhood } \\
\text { psychopathology, and } \\
\text { whether maternal } \\
\text { depression affect the } \\
\text { security of attachment at } \\
\text { twelve months of age in a } \\
\text { low-income sample. }\end{array}$ & $\begin{array}{l}\text { Mothers from high-risk } \\
\text { (low income) group. } \\
\qquad N=56 ; \\
\text { (M age = NA; SD = NA) }\end{array}$ & $\begin{array}{c}\text { SSP: } 12 \text { months; } \\
\text { CES-D: } 0-9 \text { month and } 18 \\
\text { months }\end{array}$ & $\begin{array}{c}\text { Depressed and } \\
\text { non-depressed mothers } \\
\text { did not differ in incidence } \\
\text { of insecure infant } \\
\text { attachment, nor did the } \\
\text { maternal depression } \\
\text { scores correlate with } \\
\text { infant reunion behaviors } \\
\text { in the strange situation, } \\
\text { including infant } \\
\text { avoidance or resistance at } \\
\text { reunion. Mothers } \\
\text { reporting mild to } \\
\text { moderate depression were } \\
\text { more likely to have } \\
\text { securely attached infants, } \\
\text { while mothers reporting } \\
\text { severe depression were } \\
\text { more likely to have } \\
\text { infants showing unstable } \\
\text { avoidant attachment. } \\
\text { More surprisingly, } \\
\text { mothers reporting the } \\
\text { least frequent depressive } \\
\text { symptoms were more } \\
\text { likely to have avoidant } \\
\text { infants. }\end{array}$ & $\begin{array}{c} \\
\text { Adequate sample size } \\
\text { with no information about } \\
\text { attrition rate. Validated } \\
\text { methods, used } \\
\text { double-blind procedure, } \\
\text { clear methodology and } \\
\text { statistical analysis, direct } \\
\text { measurement of } \\
\text { depression-attachment } \\
\text { influence. No clear } \\
\text { information if SSP coders } \\
\text { have some experience. No } \\
\text { representative high-risk } \\
\text { population. }\end{array}$ \\
\hline
\end{tabular}

ADS-L—German version of CES-D; AQS—Attachment Behaviour Q-Sort; BD—Beck Depression Inventory; BSI—Brief Symptom Inventory; CES-D—Center for Epidemiological Studies Depression; CIDI-Composite International Diagnostic Interview; DACL-The Depression Adjective Check Lists; EPDS-Edinburgh Postnatal Depression Scale; HRSD-Hamilton Rating Scale for Depression; IDD-Inventory to Diagnose Depression; PCERA-The Parent-Child Early Relational Assessment Scale; PSE-Standardized Psychiatric Interview Present State Examination; SADS-L-Schedule for Affective Disorders and Schizophrenia; SCID-Structured Clinical Interview for DSM-IV; SCID-NP-Structured Clinical Interview for DSM-IV—Non-Patient Version; SPI—Standardized Psychiatric Interview; SSP-Strange Situation Procedure; TAS-45—Toddler Attachment Sort—short version of Attachment Q Sort. 


\subsection{The Influence of Major Depression on Attachment Style}

Four studies evaluated the relation between maternal depression in the lifespan and child attachment style [25,44-46], two of which showed no such association [45,46]. Carter et al. [25] reports a higher incidence of insecure attachment among infants of a group characterised by depression with comorbidities compared to those of a 'pure' depression group and a no-symptoms group. A study of infant attachment and prenatal depression in mothers with a history of major depressive episodes [44] found the effect of such depression to be moderated by less than optimal maternal parenting quality. A history of major depressive disorders was found to affect child attachment style only when depression coexists with another mental disorder, or when it appears prior to the antenatal period.

\subsection{The Influence of Prenatal Depression on Attachment Style}

Three empirical studies have evaluated the associations between maternal prenatal depression and child attachment patterns $[44,46,63]$. Only one of these was conducted on a varied and representative sample with socio-economic diversity; it found no relationship between insecure and disorganised attachment patterns and maternal prenatal diagnosis of depression, regardless of its severity, or maternal depressive symptoms during pregnancy [46]. In addition, no association was found between child attachment style and the maternal experience of loss and prenatal depression, even in studies involving women after stillbirth [63]. Nevertheless, infants born subsequent to a previous stillbirth were significantly more likely to express disorganised attachment patterns than those in the control group. Only one study found a significant association between maternal prenatal depression and a disorganised attachment style by the child [44]; this was observed in mothers with a history of major depressive episodes.

\subsection{The Influence of Postnatal Depression on Attachment Style}

The relationship between the occurrence of maternal depression symptoms in the postpartum period and child attachment style was evaluated in 28 of the studies included in this review. Of these, 13 found no such relationship [39,41-44,46,56-58,61-64], four studies found a weak influence [35,49, $54,60]$ and 11 found a moderate association $[40,45,47,49-52,54,58,64]$. The studies linked the effects of postnatal depression to a variety of factors. The most important of them are socio-economic status, type and timeframe of depression measurement.

\subsubsection{High-Risk Groups}

The high-risk groups included participants with psychosocial and/or socio-demographic risk factors, i.e., poor financial situation, adolescent mothers, mothers with a history of stillbirth, mothers of children with very low birth weight. Six papers found no relation between maternal depression and child attachment style $[39,43,44,55,56,62]$, three showed a weak link [35,53,59]. Two studies found a significant interaction [45,50]; however, both used a structured interview to measure depression. In contrast, out of six studies that found no dependence, only one was based on structured interviews [44].

Maternal postpartum depression in high-risk groups was not found to be a significant predictor of attachment security/insecurity among mothers with borderline personality pathology [39], mothers with histories of major depressive episodes [44], or women who have experienced stillbirth just before the current pregnancy [63].

A study by Lyons-Ruth et al. [35] found that high-risk infants from families demonstrating the combined effects of poverty, maternal depression and caretaking inadequacy had a significantly higher rate of insecure-disorganised attachment than a community sample. Measelle and Ablow [54] found higher maternal depressive symptoms to be associated with higher levels of pro-inflammatory cytokines, but only among children with insecure attachment style. In the study with adolescent mothers [60], depression was a marginal link with an attachment style. The most important factor in their case was not depression, but maternal sensitivity. 


\subsubsection{Type of Measurement and Timeframe of the Examination of Depression}

In 12 studies, depression was measured using psychiatric or structured interviews. In nine of them, depression had a significant impact on the child's attachment style [25,40,45,47-52]. Only in three studies was no significant correlation observed between the diagnosed depression and the child's insecure attachment style $[41,44,46]$. Two of the three studies had very small sample size $[41,44]$. In contrast, 17 studies measured the depressive mood using self-report inventories; of these, only four found it to have a significant relationship with the child's attachment style $[53,55,59,65]$.

The studies varied with regard to the time when maternal depression was measured. Generally, although correlations were observed between attachment style and maternal depression measured while the child was young, i.e., up to three months, these relationships became less significant when maternal depression was measured at later stages. Interestingly, studies that evaluated depression only at later stages, i.e. between six and 18 months, found no such relationship $[35,39,41,43,58]$. This is best illustrated by Bigelow et al. [53], who established that the risk of maternal depression decreased during the first year of life, with the sharpest decline observed between six weeks and four months, and indicated that the degree of disorganised attachment behaviour at 12 months was positively associated with the risk of maternal depression at six weeks. Similarly, Donovan and Leavitt [65] found that mothers of insecurely attached infants were more depressed than those of securely-attached children at five months; however, no such relationship was observed at 16 months. A similar pattern was observed by Righetti-Veltema et al. [51] where depressive symptomatology, as detected at three months postpartum, had an impact on attachment style 15 months later, despite the fact that most mothers no longer presented depressive symptoms at 18 months. Beeghly et al. [55] reported that maternal depressive symptoms were associated with attachment security at two to three months and at six months, and to a lesser extent at 12 months, but only amongst male infants. Such associations were no longer significant when depressive symptoms were measured at 18 months. Tomlinson et al. [50] reported the same association at two months postpartum.

No diminished relationship was observed between maternal depression and attachment style in later months in Gravener et al. [40] and Toth et al. [48]. The two studies found that the distribution of attachment classifications measured at 20 months differed significantly between a group of infants and mothers with postnatal major depression and a control group of mothers with no depressive symptoms, with lower rates of secure attachment and higher rates of disorganised attachment being found in the depressed group. A similar relation was also found at four, 12 and 15 months by McMahon et al. [49].

Measelle and Ablow [54] report a very weak association between depression and attachment style; however, in this case, depression was measured according to the mean of two measurements taken at the fifth and seventeenth month postpartum by self-report inventory. Other studies report no association between attachment style and depression measured at six weeks [63], at two months [62,63] and at six months [44].

\subsubsection{Studies Conducted on Representative and Large Groups}

Ten out of the 29 papers included in this review describe studies conducted on representative community samples. Five of them report a significant relation between maternal depression and child attachment style $[48,49,52,53,59]$, while the other five did not $[46,58,61,63,64]$.

Three of the studies were conducted on very large samples. Of these, Tharner et al. [46] $(N=627)$ and Sagi et al. [61] $(N=758)$ found no relationship between the maternal postpartum depression and child attachment style. However, Zaslow et al. [59] $(N=7894)$ found attachment insecurity to be positively associated with maternal postpartum depression, although it is important to note that maternal depression was measured only at nine months postpartum and that depression was also linked to poor parenting practices and household food insecurity. 


\subsection{Factors that Modify Depression-Attachment Link}

\subsubsection{Demographic Factors}

Of the six studies with a focus on maternal age $[42,46,49,53,55,56]$ none found it to have any connection with attachment style. Even when maternal age correlated with depression risk, the indirect effect was also not significant [53]. The associations between maternal education and attachment security are unclear: while three studies report a lack of association $[46,59,60]$, one of them examining only young mothers aged 19 years or under [60], two other studies [49,64] indicated a strong relationship between the level of maternal education and child attachment. Interestingly, Clark-Stewart et al. [64] reported that maternal education was more important for attachment security than family structure (single vs. dual parent families), and McMahon et al. [49] indicated that a lower level of education was connected with more severe depression, as well as with an insecure internal working model and hence with child insecurity; however, the presence of unequal or small sample sizes in both studies may limit these findings.

Four studies analysed family income or socioeconomic status (SES) individually or as a cumulative demographic risk, but with inconclusive results. Beeghly et al. [55] revealed a weak correlation between child perceived security and familial demographic risk factors, including SES, family income, child sex, maternal age, education and marital status; however, this was only observed for boys. Clarke-Stewart et al. [64] examined the association between child outcomes and family income to need, and found it to have a strong correlation with attachment security. De Falco et al. [56] examine lower child attachment security in cases characterised by a co-occurrence of psychosocial risk factors, such as low family SES and maternal psychopathology, with socio-demographic risk factors, such as young age and single parenting, and compared it with cases demonstrating socio-demographic risk alone. No significant direct correlation was observed between family SES and attachment. Tharner et al. [46] report that although the monthly family income was the lowest in the resistant attachment group, no significant income differences existed between any of the attachment groups; even so, it should be noted that the study participants had a relatively high socioeconomic status.

\subsubsection{Psychological Factors}

Two studies found no such association between maternal psychological functioning and attachment security [46,56]. Of these, De Falco et al. [56] highlighted the small variability of their sample, which included only mothers with socio-demographic or psychosocial risk factors.

Bigelow et al. [53] analysed the association between attachment style and mother's appropriate vs. non-attuned mind-mindedness. A significant negative correlation was only found between the degree of disorganized attachment behaviour by the child, measured at 12 months, and maternal appropriate mind-mindedness, measured at four months. However, an analysis of the mediating role of appropriate mind-mindedness showed no significant association between maternal depression at six weeks postpartum and the degree of disorganized attachment behaviour by the child measured at one year.

Donovan and Leavitt [65] assessed the relationship between attachment security and maternal attributional style, as well as the perception of control over infant crying, i.e., a low, middle or high illusion of control, by the mother. No association was found between attributional style and attachment status, but high illusion of control by the mother was associated with insecure attachment. However, it should be mentioned that mothers with high illusion of control were also the most depressed.

Bergman et al. [58] found a significant relationship between maternal pre- or postnatal anxiety and attachment security: securely-attached children tended to have mothers with lower levels of postnatal anxiety. 


\subsubsection{Gynaecological-Obstetrics Factors}

Gestational age at birth and APGAR score [46], birth weight and caesarean section, the use of reproductive technology, number of days spent at hospital after delivery and singleton/multiple pregnancy [57] have been found to be associated with attachment security. Two studies examined also the role of unplanned pregnancy [50,57], but even though an unplanned pregnancy was related to early maternal depression [50], none of the studies found it to influence attachment security. Mehler et al. [57] noted that although securely-attached preterm infants tended to be breastfed more frequently than those who were insecurely attached, the difference was not significant.

Furthermore, higher rates of insecure attachment [57] or avoidant attachment [46] were observed in firstborns. Children seen by their mothers soon after birth, i.e., between $30 \mathrm{~min}$ and three hours, were also more securely attached [57]. Hughes et al. [63] revealed that infants born subsequent to stillbirth were more likely to express disorganized attachment patterns than those born after uncomplicated pregnancy. These differences were strongly predicted by maternal unresolved mourning. Even though holding the dead infant and performing a funeral was not significantly associated with disorganized attachment of the next child, its likelihood was higher when mothers had seen the dead infant.

\subsubsection{Infant Factors}

Our findings reveal an equivocal association between infant sex and attachment security among the studies. Five studies showed no such association $[44,46,49,57,61]$, while four found otherwise [42, $45,51,55]$. The latter four clearly indicate that boys may be more vulnerable to early caregiving risks such as maternal depression, with negative consequences for mother-child attachment security.

Infant behaviour problems were significantly associated with attachment style [52]. Predictably, the mothers and fathers of secure children reported fewer behavioural problems in their infants. However, a more detailed analysis of the studies included in the current review revealed that parenting difficulties, poorer social support and maternal stress were better predictors of attachment style. A lack of resources available for parenting resulted in poor boundary-setting for children, which contributed to insecure attachment and behavioural problems. Moreover, these factors were not influenced by maternal depression. Neither infant development status [55] nor infant temperament $[61,65]$ predicted attachment style.

\subsubsection{Social Support and Single Parenting}

Further equivocal results were associated with single parenting. Three studies showed marital status to have no influence on attachment style $[42,46,56]$ while one study found children in one-parent families to be less securely attached to their mothers [64]. It is important to note that the single women in the study reported more symptoms of depression and were poorer than mothers in two-parent families.

The results related to partner support are not straightforward. While Donovan and Leavitt [65] indicated no influence on attachment style, other studies, including Tomlinson et al. [50], present contradictory results. The most surprising findings were provided by Tarabulsy et al. [60], who showed that greater levels of support from a partner was associated with insecure attachment. As this study included only adolescent mothers, the authors provided three hypotheses about this result: firstly, that an adolescent father may cause problematic father-infant interactions; secondly, that a father may be more disposed to being helpful when he sees that the mother of his child has emotional or maternal difficulties; thirdly, that the mother may be afraid of losing the father's affection and may not be as sensitive to her infant as she would be under normal circumstances [60].

Regarding the influence of marital satisfaction on attachment security, some studies indicate that when mother was satisfied with her relationship, there was a greater chance that she would have a securely attached child [45,61]; however, Cicchetti et al., [52] found the opposite. Two studies viewing the issue of support in a much broader context, including family and friends $[52,55]$ found 
that maternal social support does not attenuate the negative association between maternal depressive symptom trajectories and child attachment security. However, Donovan and Leavitt [65] report that mothers with alternative infant care to cover non-work related activities tended to have more securely attached children.

\subsubsection{Parenting and Emotional Availability}

Two studies explored the relations between the internal working model of relationships and maternal depression, and infant attachment style $[49,60]$. Both showed that autonomous mothers tended to have securely attached infants. In addition, McMahon et al. [49] indicated that maternal working models of early loving relationships buffered the effects of depressive symptoms on the development of an insecure attachment style. However, Tarabulsy et al. [60] indicated that the association was more complex, and highlighted that maternal sensitivity played a role. These maternal working models were no longer a significant predictor of infant attachment security when maternal sensitivity, partner support and maternal depression were considered together. These findings are consistent with studies that took the emotional availability of the mother into account $[25,61]$, all of which found greater emotional availability to be associated with a greater chance of the child developing a secure attachment style. In addition, Gratz et al. [39] indicated that maternal emotional dysfunction influenced the insecure attachment style, but did not determine whether it could be considered as a moderator for the depression-attachment relationship.

Finally, the influence of parenting quality was evaluated in four studies $[40,44,51,59]$ which showed that parenting quality, time devoted to play and interaction with the child affected the attachment style. Zaslow et al. [59] indicated that positive parenting mediated the association between maternal depression and insecure attachment style. Depression was negatively associated with positive parenting, which in turn was negatively associated with insecure attachment style. In contrast, Gravener et al. [40] proposed that maternal self-criticism may have a significant influence on attachment style.

\section{Discussion}

The literature search revealed 29 papers describing empirical studies of the effect of maternal depression on infant attachment in the first two years of a child's life, more specifically, the role of a lifetime history of major depression or of depression that occurred during the pre- and/or postnatal period. These studies, therefore, examined mothers from a range of backgrounds, and with considerable variation in symptom severity, duration and dynamics; however, despite such diversity, most studies do not indicate that maternal depression plays any role in determining infant attachment. Nevertheless, 13 of the 29 studies included in our present analysis indicated no such relationship. Therefore, the present review attempted to identify the factors behind such divergent results.

The distinction between major depression and depressed mood turned out to be crucial. If depression was diagnosed by structured interview, it was commonly found to have a significant influence on child attachment style, as demonstrated in nine studies out of 12 . However, if questionnaires such as the CES-D or BDI were used, depressive mood was commonly found to be unrelated to attachment style, as noted in 12 studies out of 17 . Hence, the use of an accurate and reliable diagnosis of depression is crucial in a study, and should be one of the gold standards for studies on the effects of depression on attachment.

Our findings do not confirm that antenatal or prenatal depression plays any role in infant attachment. Only one examined study identified an association between antenatal depression and attachment style, but all the women participating in that study had a history of major depression [44]. The presence of antenatal or prenatal depressive symptoms increases the risk of occurrence of an insecure attachment style only when factors such as low parental quality [44] or comorbid diagnosis [25] coexist with depression.

Our investigations showed that even in case of high-risk groups $[35,39,43,54,56,57]$ depression did not affect the attachment style, or that a very weak association existed [60]. 
The studies that do take into account postpartum depression, however, suggest that it does have an effect on attachment, but only under certain conditions, such as the time at which depression was diagnosed. It is worth stressing, however, that the examination of postpartum depression should be made before the sixth month after birth. Most studies that included a diagnosis of depression after this time showed no relationship between depression and attachment style.

It is likely that the differences between results may be attributed to the fact that the participants of some studies had a long history of depressive symptoms and suffered from postpartum depression, while in others, major depression had only begun after the recent delivery. If only severe and chronic symptoms of depression increase the risk of insecure attachment, the question is whether these relate to the effect of depression or the effect of factors that usually accompany mood disorders (e.g., parental quality, maternal sensitivity, emotional availability).

However, our findings confirm the claim that depressive mothers are not a homogeneous group. This is in line with the view that depressive mothers are able to create very good conditions for raising their children, regardless of the severity of symptoms [66], and that no significant relation exists between depressive symptoms and quality of infant care [67]. Therefore, the role of maternal sensitivity, emotional availability and time devoted to a child is more important than the presence of depression itself $[25,39,60,61]$. The need for care enforces an increase in activity and focuses the mother's attention on the child's needs, which can reduce the severity of depression symptoms. The difficulties she experiences can also be interpreted as related to the new role. If so, the possible negative effects of depression might be compensated by maternal involvement in childcare.

The most surprising results of our systematic review are associated with breastfeeding. Among 29 studies, only two took this factor into account [42,57]. It is unclear why this factor is overlooked by so many studies, despite the fact that a body of data suggests that longer duration of breastfeeding is associated with attachment security $[46,68,69]$, and only a few studies show no such association [70]. Verifying whether breastfeeding moderates the impact of depression on attachment appears a very interesting topic, especially as shorter breastfeeding duration is associated with postpartum depression in almost all studies [71]. Thus, future studies should consider breastfeeding and its duration to verify its role as a factor that, when combined with maternal depression, affects attachment security.

In summary, our findings indicate that maternal depression is found to be linked to attachment security more often when it occurs postnatally and when is diagnosed by structured interview [25, 44,45,47-52] and not by self-reporting measures. The findings also indicate factors that increase the likelihood of maternal depression becoming a risk for attachment insecurity. Such identified factors include severe and long-lasting depressive symptoms, coexistence of depression in the pre- and postnatal period and the family being in a difficult socioeconomic situation. The longitudinal studies included in the review also indicate that maternal depression changes with time [51], and as such, its effect might depend on the time of measurement (up to six months postpartum). This effect has also been found to vary between male and female infants [55].

Our findings have applications for clinical practice. Firstly, they indicate that if maternal depression is to be diagnosed, it should rather be done by clinical interview and not self-reported questionnaire, as the latter is susceptible to social desirability effects. In societies with high respect and high expectations related to the maternal role, women might feel reluctant to reveal a low mood or other depressive symptoms that may be inconsistent with socially expected maternal joy and satisfaction. A standardized interview conducted by a well-trained and supportive clinician provides more accurate data and creates better circumstances for opening a discussion of the different experiences of a new mother. In addition, while a clinical interview allows postnatal depression to be diagnosed even after a few weeks, questionnaire methods only indicate the presence of dispiritedness and worsened mood in the mother. Secondly, new mothers should be screened for depression reasonably early on, as it is the incidence of depression in the first six months postpartum that affects a child's attachment security. Early detection of depression also allows for earlier implementation of proper intervention. 
Strengths and Limitations of the Study

The present review has both strengths and limitations. Most importantly, it differs from other literature reviews in this area by directly analysing the relationship between maternal depression and child attachment $[29,30]$. Similarly, none of the four meta-analyses conducted so far have examined the distinction between antenatal/prenatal and postnatal depression [72-75]. Only Martins and Gaffan [74] stated the age of the child at which the symptoms of depression in mothers were measured as part of the studies covered in their meta-analysis.

Another strength of our study is that it performs a rigorous quality assessment of each included manuscript. The assessment was performed in compliance with Cochrane's recommendations [37]. Therefore, the final conclusions could be formulated while taking into account the potential risk of bias resulting from factors such as non-representative and inadequate sample size [56].

A further strength, but also a limitation, is that the analysed studies were diversional: they have a longitudinal design $[53,62,64]$, use reliable measures to identify depression and classify attachment [44, 63], and are based on large representative samples [46,59].

On the positive side, this diversity of source materials highlights the role played by the time at which depressive symptoms were measured or diagnosed in determining their impact on attachment. On the other hand, some studies were based on smaller samples [65] or included participants with particular characteristics, such as adolescent mothers [60] or women with a history of stillbirth [63]. Although such unique features can help better understand the situation of these particular groups of women, it might not be possible to generalize these results. As the strange situation procedure has frequently been used to classify infant attachment, such studies return comparable results, and although studies may refer to insecure attachment style, they conceptualize it in the same way. Most of the included papers are based on studies with moderate to high quality (Tables 1 and 2), indicating that their findings are reliable, irrespective of whether they confirm any depression-attachment link.

Another limitation is that some studies were based on cross-sectional designs [39-43] and hence cannot be used to indicate predictive risk. Therefore, although none of them indicate the existence of such a relationship, it is impossible to conclude that it does not exist.

In addition, as one of the inclusion criteria was English as the language of the publication, further data may exist in papers published in other languages. Furthermore, the size of the samples employed by the studies varied, and only a few included large, representative groups; the participants varied with regard to demographic characteristics, and family and socioeconomic status, and although the studies were conducted in several countries, the vast majority of participants were White-Caucasian women, which might limit the generalization of the findings to other ethnic groups. Finally, as the review included studies with a focus on the association between maternal depression and attachment security, its findings cannot be extended to other effects of maternal depression, such as infant cognitive development or behavioural problems; nevertheless, some of the studies included addressed also these broader issues [64].

Another important consideration is that there is little, if any, replicability between individual studies. Some of the reviewed studies confirm the impact of depression, while others do not, with only some of the discrepancies being explained by factors such as the time at which depression was measured [53,58]. Nevertheless studies conducted under similar conditions and with similar samples differ in their results $[39,45,49,64]$. Such divergence is clearly visible in the light of recent reports from the ManyLabs project, which fails to replicate many psychological studies [76]. Despite so many years of research in this area, there is still a need for replication.

\section{Conclusions}

Our findings indicate that the association between maternal depression and infant attachment is a complex and dynamic one. It is affected by such factors as the type of depression, method and time of measurement, as well as a number of maternal factors, such as education or self-criticism, and also by infant factors, such as being male or firstborn. Therefore, future studies in this area 
should consider possible confounding factors, and a multifactorial and prospective approach should be applied when designing their research protocols. Further studies should also attempt to incorporate greater cultural and ethnic diversity and aim to confirm, or refute, the assumption that the effect of maternal depression on infant attachment security is universal under similar circumstances.

Supplementary Materials: The following are available online at http:/www.mdpi.com/1660-4601/17/8/2675/s1, Table S1: Quality assessment scores; Demographic characteristic of systematic review samples.

Author Contributions: Conceptualization, A.Ś., K.K., K.J., J.Ś. and E.B.-B.; methodology, A.Ś. and K.K.; software, A.Ś. and K.K.; formal analysis, A.Ś., K.K., K.J., J.Ś. and E.B.-B.; investigation, A.Ś., K.K., K.J. and J.Ś.; resources, A.S. and K.K.; data curation, A.Ś. and K.K.; writing—original draft preparation, A.S.., K.K., K.J., J.S. and E.B.-B.; writing—review and editing, A.Ś., K.K. and E.B.-B.; visualization, A.S.'; supervision, E.B.-B.; project administration, A.Ś. All authors have read and agreed to the published version of the manuscript.

Funding: This research received no external funding.

Conflicts of Interest: The authors declare no conflict of interest.

\section{References}

1. Kessler, R.C.; Bromet, E.J. The Epidemiology of Depression across Cultures. Annu. Rev. Public Health 2013, 34, 119-138. [CrossRef] [PubMed]

2. Wang, J.; Wu, X.; Lai, W.; Long, E.; Zhang, X.; Li, W.; Zhu, Y.; Chen, C.; Zhong, X.; Liu, Z.; et al. Prevalence of depression and depressive symptoms among outpatients: A systematic review and meta-analysis. BMJ Open 2017, 7, e017173. [CrossRef] [PubMed]

3. Brummelte, S.; Galea, L.A.M. Postpartum depression: Etiology, treatment and consequences for maternal care. Horm. Behav. 2016, 77, 153-166. [CrossRef] [PubMed]

4. van de Loo, K.F.E.; Vlenterie, R.; Nikkels, S.J.; Merkus, P.J.F.M.; Roukema, J.; Verhaak, C.M.; Roeleveld, N.; van Gelder, M.M.H.J. Depression and anxiety during pregnancy: The influence of maternal characteristics. Birth 2018, 45, 478-489. [CrossRef]

5. O'Hara, M.W.; Wisner, K.L. Perinatal mental illness: Definition, description and aetiology. Best Pract. Res. Clin. Obstet. Gynaecol. 2014, 28, 3-12. [CrossRef]

6. Stuart-Parrigon, K.; Stuart, S. Perinatal Depression: An Update and Overview. Curr. Psychiatry Rep. 2014, 16, 467-476. [CrossRef]

7. Wisner, K.L.; Moses-Kolko, E.L.; Sit, D.K.Y. Postpartum depression: A disorder in search of a definition. Arch. Womens Ment. Health 2010, 13, 37-40. [CrossRef]

8. O'Hara, M.W.; McCabe, J.E. Postpartum Depression: Current Status and Future Directions. Annu. Rev. Clin. Psychol. 2013, 9, 379-407. [CrossRef]

9. Banti, S.; Mauri, M.; Oppo, A.; Borri, C.; Rambelli, C.; Ramacciotti, D.; Montagnani, M.S.; Camilleri, V.; Cortopassi, S.; Rucci, P.; et al. From the third month of pregnancy to 1 year postpartum. Prevalence, incidence, recurrence, and new onset of depression. Results from the Perinatal Depression-Research \& Screening Unit study. Compr. Psychiatry 2011, 52, 343-351.

10. Gavin, N.I; Gaynes, B.N.; Lohr, K.N.; Meltzer-Brody, S.; Gartlehner, G.; Swinson, T. Perinatal Depression: A Systematic Review of Prevalence and Incidence. Obstet. Gynecol. 2005, 106, 1071-1083. [CrossRef]

11. Gelaye, B.; Rondon, M.B.; Araya, R.; Williams, M.A. Epidemiology of maternal depression, risk factors, and child outcomes in low-income and middle-income countries. Lancet Psychiatry 2016, 3, 973-982. [CrossRef]

12. Guo, N.; Robakis, T.; Miller, C.; Butwick, A. Prevalence of Depression among Women of Reproductive Age in the United States. Obstet. Gynecol. 2018, 131, 671-679. [CrossRef] [PubMed]

13. Dubber, S.; Reck, C.; Müller, M.; Gawlik, S. Postpartum bonding: The role of perinatal depression, anxiety and maternal-fetal bonding during pregnancy. Arch. Womens Ment. Health 2015, 18, 187-195. [CrossRef] [PubMed]

14. Forman, D.R.; O'Hara, M.W.; Stuart, S.; Gorman, L.L.; Larsen, K.E.; Coy, K.C. Effective treatment for postpartum depression is not sufficient to improve the developing mother-child relationship. Dev. Psychopathol. 2007, 19, 585-602. [CrossRef] 
15. O'Higgins, M.; Roberts, I.S.J.; Glover, V.; Taylor, A. Mother-child bonding at 1 year; associations with symptoms of postnatal depression and bonding in the first few weeks. Arch. Womens Ment. Health 2013, 16, 381-389. [CrossRef]

16. Perry, D.F.; Ettinger, A.K.; Mendelson, T.; Le, H.-N. Prenatal depression predicts postpartum maternal attachment in low-income Latina mothers with infants. Infant Behav. Dev. 2011, 34, 339-350. [CrossRef]

17. Nonnenmacher, N.; Noe, D.; Ehrenthal, J.C.; Reck, C. Postpartum bonding: The impact of maternal depression and adult attachment style. Arch. Womens Ment. Health 2016, 19, 927-935. [CrossRef]

18. Klier, C.M. Mother-infant bonding disorders in patients with postnatal depression: The Postpartum Bonding Questionnaire in clinical practice. Arch. Womens Ment. Health 2006, 9, 289-291. [CrossRef]

19. Tronick, E.; Reck, C. Infants of Depressed Mothers. Harv. Rev. Psychiatry 2009, 17, 147-156. [CrossRef]

20. Brennan, P.A.; Hammen, C.; Andersen, M.J.; Bor, W.; Najman, J.M.; Williams, G.M. Chronicity, severity, and timing of maternal depressive symptoms: Relationships with child outcomes at age 5. Dev. Psychol. 2000, 36, 759-766. [CrossRef]

21. Trapolini, T.; McMahon, C.A.; Ungerer, J.A. The effect of maternal depression and marital adjustment on young children's internalizing and externalizing behaviour problems. Child Care Health Dev. 2007, 33, 794-803. [CrossRef] [PubMed]

22. Murray, L.; Arteche, A.; Fearon, P.; Halligan, S.; Croudace, T.; Cooper, P. The effects of maternal postnatal depression and child sex on academic performance at age 16 years: A developmental approach: PND \& child cognitive and academic outcomes. J. Child Psychol. Psychiatry 2010, 51, 1150-1159. [PubMed]

23. Feldman, R.; Granat, A.; Pariente, C.; Kanety, H.; Kuint, J.; Gilboa-Schechtman, E. Maternal Depression and Anxiety Across the Postpartum Year and Infant Social Engagement, Fear Regulation, and Stress Reactivity. J. Am. Acad. Child Adolesc. Psychiatry 2009, 48, 919-927. [CrossRef] [PubMed]

24. Granat, A.; Gadassi, R.; Gilboa-Schechtman, E.; Feldman, R. Maternal depression and anxiety, social synchrony, and infant regulation of negative and positive emotions. Emotion 2017, 17, 11-27. [CrossRef] [PubMed]

25. Carter, A.S.; Garrity-Rokous, F.E.; Chazan-Cohen, R.; Little, C.; Briggs-Gowan, M.J. Maternal Depression and Comorbidity: Predicting Early Parenting, Attachment Security, and Toddler Social-Emotional Problems and Competencies. J. Am. Acad. Child Adolesc. Psychiatry 2001, 40, 18-26. [CrossRef]

26. Conroy, S.; Marks, M.N.; Schacht, R.; Davies, H.A.; Moran, P. The impact of maternal depression and personality disorder on early infant care. Soc. Psychiatry Psychiatr. Epidemiol. 2010, 45, 285-292. [CrossRef]

27. Conroy, S.; Pariante, C.M.; Marks, M.N.; Davies, H.A.; Farrelly, S.; Schacht, R.; Moran, P. Maternal Psychopathology and Infant Development at 18 Months: The Impact of Maternal Personality Disorder and Depression. J. Am. Acad. Child Adolesc. Psychiatry 2012, 51, 51-61. [CrossRef]

28. Wang, Y.; Dix, T. Patterns of depressive parenting: Why they occur and their role in early developmental risk. J. Fam. Psychol. 2013, 27, 884-895. [CrossRef]

29. Kingston, D.; Tough, S.; Whitfield, H. Prenatal and Postpartum Maternal Psychological Distress and Infant Development: A Systematic Review. Child Psychiatry Hum. Dev. 2012, 43, 683-714. [CrossRef]

30. Letourneau, N.L.; Dennis, C.-L.; Cosic, N.; Linder, J. The effect of perinatal depression treatment for mothers on parenting and child development: A systematic review. Depress. Anxiety 2017, 34, 928-966. [CrossRef]

31. Schore, A.N. Effects of a secure attachment relationship on right brain development, affect regulation, and infant mental health. Infant Ment. Health J. 2001, 22, 7-66. [CrossRef]

32. Eiden, R.D.; Edwards, E.P.; Leonard, K.E. Mother-infant and father-infant attachment among alcoholic families. Dev. Psychopathol. 2002, 14, 253-278. [CrossRef]

33. Moher, D.; Liberati, A.; Tetzlaff, J.; Altman, D.G. Preferred Reporting Items for Systematic Reviews and Meta-Analyses: The PRISMA Statement. PLoS Med. 2009, 6, 6. [CrossRef] [PubMed]

34. Vu-Ngoc, H.; Elawady, S.S.; Mehyar, G.M.; Abdelhamid, A.H.; Mattar, O.M.; Halhouli, O.; Vuong, N.L.; Ali, C.D.M.; Hassan, U.H.; Kien, N.D.; et al. Quality of flow diagram in systematic review and/or meta-analysis. PLoS ONE 2018, 13, e0195955. [CrossRef] [PubMed]

35. Lyons-Ruth, K.; Connell, D.B.; Grunebaum, H.U.; Botein, S. Infants at Social Risk: Maternal Depression and Family Support Services as Mediators of Infant Development and Security of Attachment. Child Dev. 1990, 61, 85-98. [CrossRef]

36. Higgins, J.P.T.; Green, S. Cochrane Handbook for Systematic Reviews of Interventions; John Wiley \& Sons Ltd.: Chichester, UK, 2011; ISBN 978-0-470-05796-4. 
37. Higgins, J.P.T.; Altman, D.G.; Sterne, J.A.C. Assessing risk of bias in included studies. In Cochrane Handbook for Systematic Reviews of Interventions; Higgins, J.P.T., Green, S., Eds.; John Wiley \& Sons Ltd.: Chichester, UK, 2011; pp. 8.1-8.53, ISBN 978-0-470-05796-4.

38. Kjaergard, L.L.; Villumsen, J.; Gluud, C. Reported Methodologic Quality and Discrepancies between Large and Small Randomized Trials in Meta-Analyses. Ann. Intern. Med. 2001, 135, 982-989. [CrossRef]

39. Gratz, K.L.; Kiel, E.J.; Latzman, R.D.; Elkin, T.D.; Moore, S.A.; Tull, M.T. Meternal Borderline Personality Pathology and Infant Emotion Regulation: Examining Emotion-Related Difficulties and Infant Attachment. J. Personal. Disord. 2014, 28, 52-69. [CrossRef]

40. Gravener, J.A.; Rogosch, F.A.; Oshri, A.; Narayan, A.J.; Cicchetti, D.; Toth, S.L. The Relations among Maternal Depressive Disorder, Maternal Expressed Emotion, and Toddler Behavior Problems and Attachment. J. Abnorm. Child Psychol. 2012, 40, 803-813. [CrossRef]

41. Laurent, H.K.; Ablow, J.C. The missing link: Mothers' neural response to infant cry related to infant attachment behaviors. Infant Behav. Dev. 2012, 35, 761-772. [CrossRef]

42. Ludmer, J.A.; Gonzalez, A.; Kennedy, J.; Masellis, M.; Meinz, P.; Atkinson, L. Association between maternal childhood maltreatment and mother-infant attachment disorganization: Moderation by maternal oxytocin receptor gene and cortisol secretion. Horm. Behav. 2018, 102, 23-33. [CrossRef]

43. Lyons-Ruth, K.; Zoll, D.; Connell, D.; Grunebaum, H.U. The depressed mother and her one-year-old infant: Environment, interaction, attachment, and infant development. New Dir. Child Adolesc. Dev. 1986, 1986, 61-82. [CrossRef] [PubMed]

44. Hayes, L.J.; Goodman, S.H.; Carlson, E. Maternal antenatal depression and infant disorganized attachment at 12 months. Attach. Hum. Dev. 2013, 15, 133-153. [CrossRef] [PubMed]

45. Murray, L. The Impact of Postnatal Depression on Infant Development. J. Child Psychol. Psychiatry 1992, 33, 543-561. [CrossRef] [PubMed]

46. Tharner, A.; Luijk, M.P.C.M.; van IJzendoorn, M.H.; Bakermans-Kranenburg, M.J.; Jaddoe, V.W.V.; Hofman, A.; Verhulst, F.C.; Tiemeier, H. Maternal lifetime history of depression and depressive symptoms in the prenatal and early postnatal period do not predict infant-mother attachment quality in a large, population-based Dutch cohort study. Attach. Hum. Dev. 2012, 14, 63-81. [CrossRef]

47. Smith-Nielsen, J.; Tharner, A.; Steele, H.; Cordes, K.; Mehlhase, H.; Vaever, M.S. Postpartum depression and infant-mother attachment security at one year: The impact of co-morbid maternal personality disorders. Infant Behav. Dev. 2016, 44, 148-158. [CrossRef]

48. Toth, S.L.; Rogosch, F.A.; Sturge-Apple, M.; Cicchetti, D. Maternal Depression, Children's Attachment Security, and Representational Development: An Organizational Perspective. Child Dev. 2009, 80, 192-208. [CrossRef]

49. McMahon, C.A.; Barnett, B.; Kowalenko, N.M.; Tennant, C.C. Maternal attachment state of mind moderates the impact of postnatal depression on infant attachment. J. Child Psychol. Psychiatry 2006, 47, 660-669. [CrossRef]

50. Tomlinson, M.; Cooper, P.; Murray, L. The Mother-Infant Relationship and Infant Attachment in a South African Peri-Urban Settlement. Child Dev. 2005, 76, 1044-1054. [CrossRef]

51. Righetti-Veltema, M.; Bousquet, A.; Manzano, J. Impact of postpartum depressive symptoms on mother and her 18-month-old infant. Eur. Child Adolesc. Psychiatry 2003, 12, 75-83. [CrossRef]

52. Cicchetti, D.; Rogosch, F.A.; Toth, S.L. Maternal depressive disorder and contextual risk: Contributions to the development of attachment insecurity and behavior problems in toddlerhood. Dev. Psychopathol. 1998, 10, 283-300. [CrossRef]

53. Bigelow, A.E.; Beebe, B.; Power, M.; Stafford, A.-L.; Ewing, J.; Egleson, A.; Kaminer, T. Longitudinal relations among maternal depressive symptoms, maternal mind-mindedness, and infant attachment behavior. Infant Behav. Dev. 2018, 51, 33-44. [CrossRef] [PubMed]

54. Measelle, J.R.; Ablow, J.C. Contributions of early adversity to pro-inflammatory phenotype in infancy: The buffer provided by attachment security. Attach. Hum. Dev. 2018, 20, 1-23. [CrossRef] [PubMed]

55. Beeghly, M.; Partridge, T.; Tronick, E.; Muzik, M.; Rahimian Mashhadi, M.; Boeve, J.L.; Irwin, J.L. Associations between early maternal depressive symptom trajectories and toddlers' felt security at 18 months: Are boys and girls at differential risk? Infant Ment. Health J. 2017, 38, 53-67. [CrossRef] [PubMed]

56. De Falco, S.; Emer, A.; Martini, L.; Rigo, P.; Pruner, S.; Venuti, P. Predictors of mother-child interaction quality and child attachment security in at-risk families. Front. Psychol. 2014, 5, 1-10. [CrossRef] [PubMed] 
57. Mehler, K.; Wendrich, D.; Kissgen, R.; Roth, B.; Oberthuer, A.; Pillekamp, F.; Kribs, A. Mothers seeing their VLBW infants within $3 \mathrm{~h}$ after birth are more likely to establish a secure attachment behavior: Evidence of a sensitive period with preterm infants? J. Perinatol. 2011, 31, 404-410. [CrossRef] [PubMed]

58. Bergman, K.; Sarkar, P.; Glover, V.; O'Connor, T.G. Maternal Prenatal Cortisol and Infant Cognitive Development: Moderation by Infant-Mother Attachment. Biol. Psychiatry 2010, 67, 1026-1032. [CrossRef]

59. Zaslow, M.; Bronte-Tinkew, J.; Capps, R.; Horowitz, A.; Moore, K.A.; Weinstein, D. Food Security During Infancy: Implications for Attachment and Mental Proficiency in Toddlerhood. Matern. Child Health J. 2009, 13, 66-80. [CrossRef]

60. Tarabulsy, G.M.; Bernier, A.; Provost, M.A.; Maranda, J.; Larose, S.; Moss, E.; Larose, M.; Tessier, R. Another Look Inside the Gap: Ecological Contributions to the Transmission of Attachment in a Sample of Adolescent Mother-Infant Dyads. Dev. Psychol. 2005, 41, 212-224. [CrossRef]

61. Sagi, A.; Koren-Karie, N.; Gini, M.; Ziv, Y.; Joels, T. Shedding Further Light on the Effects of Various Types and Quality of Early Child Care on Infant-Mother Attachment Relationship: The Haifa Study of Early Child Care. Child Dev. 2002, 73, 1166-1186. [CrossRef]

62. Edhborg, M.; Lundh, W.; Seimyr, L.; Widström, A.-M. The long-term impact of postnatal depressed mood on mother-child interaction: A preliminary study. J. Reprod. Infant Psychol. 2001, 19, 61-71. [CrossRef]

63. Hughes, P.; Turton, P.; Hopper, E.; McGauley, G.A.; Fonagy, P. Disorganised Attachment Behaviour among Infants Born Subsequent to Stillbirth. J. Child Psychol. Psychiatry 2001, 42, 791-801. [CrossRef] [PubMed]

64. Clarke-Stewart, K.A.; Vandell, D.L.; McCartney, K.; Owen, M.T.; Booth, C. Effects of Parental Separation and Divorce on Very Young Children. J. Fam. Psychol. 2000, 14, 304-326. [CrossRef] [PubMed]

65. Donovan, W.L.; Leavitt, L.A. Maternal Self-Efficacy and Infant Attachment: Integrating Physiology, Perceptions, and Behavior. Child Dev. 1989, 60, 460. [CrossRef] [PubMed]

66. Fihrer, I.; McMahon, C. Maternal state of mind regarding attachment, maternal depression and children's family drawings in the early school years. Attach. Hum. Dev. 2009, 11, 537-556. [CrossRef]

67. Fathi, F.; Mohammad-Alizadeh-Charandabi, S.; Mirghafourvand, M. Maternal self-efficacy, postpartum depression, and their relationship with functional status in Iranian mothers. Women Health 2018, 58, 188-203. [CrossRef]

68. Gibbs, B.G.; Forste, R.; Lybbert, E. Breastfeeding, Parenting, and Infant Attachment Behaviors. Matern. Child Health J. 2018, 22, 579-588. [CrossRef]

69. Weaver, J.M.; Schofield, T.J.; Papp, L.M. Breastfeeding duration predicts greater maternal sensitivity over the next decade. Dev. Psychol. 2018, 54, 220-227. [CrossRef]

70. Britton, J.R.; Britton, H.L.; Gronwaldt, V. Breastfeeding, Sensitivity, and Attachment. Pediatrics 2006, 118, e1436-e1443. [CrossRef]

71. Dias, C.C.; Figueiredo, B. Breastfeeding and depression: A systematic review of the literature. J. Affect. Disord. 2015, 171, 142-154. [CrossRef]

72. Atkinson, L.; Paglia, A.; Coolbear, J.; Niccols, A.; Parker, K.C.H.; Guger, S. Attachment security A meta-analysis of maternal mental health correlates. Clin. Psychol. Rev. 2000, 20, 1019-1040. [CrossRef]

73. Barnes, J.; Theule, J. Maternal depression and infant attachment security: A meta-analysis. Infant Ment. Health J. 2019, 40, 817-834. [CrossRef] [PubMed]

74. Martins, C.; Gaffan, E.A. Effects of Early Maternal Depression on Patterns of Infant-Mother Attachment: A Meta-analytic Investigation. J. Child Psychol. Psychiatry 2000, 41, 737-746. [CrossRef] [PubMed]

75. Van Ijzendoorn, M.H.; Schuengel, C.; Bakermans-Kranenburg, M.J. Disorganized attachment in early childhood: Meta-analysis of precursors, concomitants, and sequelae. Dev. Psychopathol. 1999, 11, 225-250. [CrossRef] [PubMed]

76. Klein, R.A.; Vianello, M.; Hasselman, F.; Adams, B.G.; Adams, R.B.; Alper, S.; Aveyard, M.; Axt, J.; Babalola, M.T.; Bahník, Š.; et al. Many Labs 2: Investigating Variation in Replicability across Sample and Setting. Assoc. Psychol. Sci. 2018, 1, 443-490. [CrossRef]

(C) 2020 by the authors. Licensee MDPI, Basel, Switzerland. This article is an open access article distributed under the terms and conditions of the Creative Commons Attribution (CC BY) license (http://creativecommons.org/licenses/by/4.0/). 